\title{
Geochemistry of buried river sediments from Ghaggar Plains, NW India: Multi-proxy records of variations in provenance, paleoclimate, and paleovegetation patterns in the Late Quaternary
}

Singh, Ajit; Paul, Debajyoti; Sinha, Rajiv; Thomsen, Kristina Jørkov; Gupta, Sanjeev

Published in:

Palaeogeography, Palaeoclimatology, Palaeoecology - An International Journal for the Geo-Sciences

Link to article, DOI:

10.1016/j.palaeo.2016.02.012

Publication date:

2016

Document Version

Peer reviewed version

Link back to DTU Orbit

Citation (APA):

Singh, A., Paul, D., Sinha, R., Thomsen, K. J., \& Gupta, S. (2016). Geochemistry of buried river sediments from Ghaggar Plains, NW India: Multi-proxy records of variations in provenance, paleoclimate, and paleovegetation patterns in the Late Quaternary. Palaeogeography, Palaeoclimatology, Palaeoecology - An International Journal for the Geo-Sciences, 449, 85-100. https://doi.org/10.1016/j.palaeo.2016.02.012

\section{General rights}

Copyright and moral rights for the publications made accessible in the public portal are retained by the authors and/or other copyright owners and it is a condition of accessing publications that users recognise and abide by the legal requirements associated with these rights.

- Users may download and print one copy of any publication from the public portal for the purpose of private study or research.

- You may not further distribute the material or use it for any profit-making activity or commercial gain

- You may freely distribute the URL identifying the publication in the public portal 


\section{Accepted Manuscript}

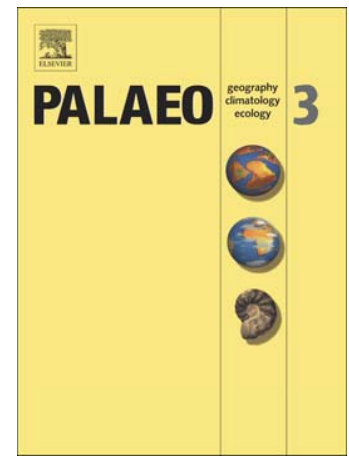

Geochemistry of buried river sediments from Ghaggar Plains, NW India: Multi - proxy records of variations in provenance, paleoclimate, and paleovegetation patterns in the late quaternary

Ajit Singh, Debajyoti Paul, Rajiv Sinha, Kristina J. Thomsen, Sanjeev Gupta

PII: $\quad$ S0031-0182(16)00084-5

DOI: $\quad$ doi: $10.1016 /$ j.palaeo.2016.02.012

Reference: $\quad$ PALAEO 7687

To appear in: $\quad$ Palaeogeography, Palaeoclimatology, Palaeoecology

Received date: 12 October 2015

Revised date: 6 February 2016

Accepted date: $\quad 8$ February 2016

Please cite this article as: Singh, Ajit, Paul, Debajyoti, Sinha, Rajiv, Thomsen, Kristina J., Gupta, Sanjeev, Geochemistry of buried river sediments from Ghaggar Plains, NW India: Multi - proxy records of variations in provenance, paleoclimate, and paleovegetation patterns in the late quaternary, Palaeogeography, Palaeoclimatology, Palaeoecology (2016), doi: 10.1016/j.palaeo.2016.02.012

This is a PDF file of an unedited manuscript that has been accepted for publication. As a service to our customers we are providing this early version of the manuscript. The manuscript will undergo copyediting, typesetting, and review of the resulting proof before it is published in its final form. Please note that during the production process errors may be discovered which could affect the content, and all legal disclaimers that apply to the journal pertain. 


\title{
Geochemistry of buried river sediments from Ghaggar Plains, NW India: multi-proxy records of variations in provenance, paleoclimate, and paleovegetation patterns in the Late Quaternary
}

\author{
Ajit Singh $^{1}$, Debajyoti Paul ${ }^{1 *}$, Rajiv Sinha ${ }^{1}$, Kristina J. Thomsen ${ }^{2}$, Sanjeev Gupta $^{3}$ \\ ${ }^{1}$ Department of Earth Sciences, Indian Institute of Technology Kanpur, India \\ ${ }^{2}$ Centre for Nuclear Technologies, Technical University of Denmark, Roskilde, Denmark \\ ${ }^{3}$ Imperial College London, London, United Kingdom \\ *Corresponding author: dpaul@iitk.ac.in
}

\begin{abstract}
We report the first geochemical record in two drill-sediment cores from a buried channel in the Ghaggar Plains of NW India, which are used to infer variations in provenance, paleoclimate, and paleovegetation in the locality during the Late Quaternary. Aeolian sediments ( $150 \mathrm{ka})$ in both the cores are overlain by fluvial sediments ( 75 ka-Recent). Major oxide composition of the core sediments $(n=35)$ generally vary between that observed for the modern-day Ghaggar/Sutlej and Yamuna river sand. The isotopic composition $\left({ }^{87} \mathrm{Sr} /{ }^{86} \mathrm{Sr}\right.$ : 0.7365 to 0.7783 and $\varepsilon_{\mathrm{Nd}}$ : -14.6 to -19.0$)$ of core sediments $(n=18)$ suggest binary mixing of sediments from compositionally distinct Higher Himalaya $(\mathrm{HH})$ and Lesser Himalaya ( $\mathrm{LH})$ endmembers in the catchment, and support involvement of a river system originating in the Himalayan hinterland. Distinctly higher ${ }^{87} \mathrm{Sr} /{ }^{86} \mathrm{Sr}$ and lower $\varepsilon_{\mathrm{Nd}}$ in the core sediments during glacial periods can be explained by increasing sediment contribution from LH (high ${ }^{87} \mathrm{Sr} /{ }^{86} \mathrm{Sr}$ and low $\varepsilon_{\mathrm{Nd}}$ ) due to an increase in glacial cover over $\mathrm{HH}$. Whereas relatively less glacial cover over $\mathrm{HH}$ during interglacial periods resulted in more erosion and sediment contribution from
\end{abstract} $\mathrm{HH}$. The down-core $\mathrm{Sr}-\mathrm{Nd}$ isotopic variability clearly reflect climate-controlled sediment erosion in the Himalayan catchment. Temporal variations in $\delta^{18} \mathrm{O}$ and $\delta^{13} \mathrm{C}$ of carbonate nodules $(n=27)$ are consistent with that reported from the Ganga interfluves. The $\delta^{13} \mathrm{C}$ variability $(-4.1$ to $1.2 \%$ ) in carbonates is mainly controlled by the extent of silicate $(\mathrm{HH})$ versus carbonate $(\mathrm{LH})$ source weathering due to significant climatic shifts. The $\delta^{13} \mathrm{C}$ of sediment organic matter $(-27.4$ to $-23.2 \%, n=24)$ suggest dominantly $\mathrm{C}_{3}$ plants in the catchment during the last $\sim 75 \mathrm{ka}$. More negative $\delta^{13} \mathrm{C}$ values in sediments during glacial periods relative to those during interglacial periods can be explained by increasing $\mathrm{C}_{4}$ abundance during interglacial periods characterized with both higher summer rainfall 
and mean annual temperature.

Keywords: Ghaggar river; alluvial sediments; carbonate nodules; isotopic composition; provenance; paleoclimate. 


\section{Introduction}

Interaction between tectonics and climate at variable spatial and temporal scales controls weathering and erosion in the catchment areas of major rivers in orogenic belts (Burbank et al., 2003; Clift et al., 2010). This influences fluvial processes such as river discharge, sediment flux, and channel migration that in turn shape the landscape in the region (Bookhagen et al., 2005). Both tectonic activities and climatic fluctuations have controlled the evolution of geomorphic landforms and sedimentary processes in the Himalayan hinterland as well as the Indus-Gangetic alluvial Plains. Further, intensified monsoon phases and corresponding high sediment fluxes during the Late Quaternary suggest a link between millennial-scale climate change and surface processes in the northwest Himalaya (Bookhagen et al., 2005). Despite more than three decades of scientific studies suggesting the existence of a network of buried channels in the Ghaggar Plains in NW India, no effort has been made to obtain a detailed geochemical record of surface and in particular subsurface sediments from the Ghaggar Plains. Consequently, temporal changes in source weathering and provenance (as a result of climate change) for the Ghaggar alluvial sediments have not been established. Several studies have attempted to reconstruct Quaternary paleoclimate of India using climate proxies in the alluvial sediments from the Ganga Plains (e.g., Galy and France-Lanord, 2001; Galy et al., 2008a; Singh et al., 2008; Lupker et al., 2012). Similar attempts have been made in the adjoining Thar region of Rajasthan, NW India using pedogenic calcretes, and lake and aeolian sediments (Singh et al., 1974; Bryson and Swain, 1981; Singhvi et al., 1982; Wasson et al., 1983; Wasson et al., 1984; Singh et al., 1990; Andrews et al., 1998; Jain and Tandon, 2003; Achyuthan et al., 2007). However, paleoclimatic reconstruction attempts on the basis of fluvial proxies in the NW India have been rather limited (e.g., Tripathi et al., 2004; Jain et al., 2005). A compilation of results on the strength of SW monsoon variability derived from continental (lake and desert sediments) proxies in the NW India and marine proxies in Arabian Sea is presented in Fig. 1.

Several researchers have used the temporal variations in ${ }^{87} \mathrm{Sr} /{ }^{86} \mathrm{Sr}$ and ${ }^{143} \mathrm{Nd} /{ }^{144} \mathrm{Nd}$ isotopic ratios in the bulk silicate fractions of alluvial sediments as a proxy to identify provenance and to infer catchment erosion in the Himalaya in response to climate change (Derry and France-Lanord, 2001; Singh et al., 2008; Rahaman et al., 2009). These studies demonstrated climate-controlled erosion of 
the Himalayan sources. On other hand, studies on the Ghaggar Plains (e.g., Tripathi et al., 2004) have not provided a clear picture of climate-controlled sedimentation dynamics. The objective of this study is to use the geochemical record of buried sediments from the Ghaggar Plains of NW India to infer temporal variations in sediment provenance, source weathering/erosion in response to climate change (glacial/interglacial periods), during the Late Quaternary. Two drilled sediment cores $(\sim 40-45 \mathrm{~m}$ deep), raised along a single transect across the buried channel and close to the modern Ghaggar river channel, near the Kalibangan village, Rajasthan, were analysed to obtain multiple geochemical data. The ${ }^{87} \mathrm{Sr} /{ }^{86} \mathrm{Sr}$ and ${ }^{143} \mathrm{Nd} /{ }^{144} \mathrm{Nd}$ ratios in bulk silicates, $\delta^{13} \mathrm{C}$ and $\delta^{18} \mathrm{O}$ in carbonate nodules, and $\delta^{13} \mathrm{C}$ of sediment organic matter in the stratigraphically-controlled samples constrained by optically stimulated luminescence (OSL) ages are compared to the available geochemical records from the NW India and the Indo-Gangetic Plains. Detailed subsurface geochemical records of fluvial sediments from NW India presented here complement the readily available extensive fluvial record from the Ganga Plains.

\section{Sampling and analytical methods}

In this study, sediment samples were taken from two ( $\sim 5 \mathrm{~m}$ deep) drill cores raised along a single transect across a buried channel, mapped by Sinha et al. (2013), near the village of Kalibangan in Rajasthan (Fig. 2a). The core sites are located on the trace of the buried channel (Yashpal et al., 1980; Sinha et al., 2013) of a large river system presumably sourced in the Himalayan hinterland (Oldham, 1893; Stein, 1942; Valdiya, 1996). The GS-10 drillcore is located at the centre of the trace of the buried channel and is $\sim 300 \mathrm{~m}$ southeast of the modern Ghaggar river. The GS-11 core is located on the southern margin of the trace of the buried channel and is $\sim 1.5 \mathrm{~km}$ southeast of the modern Ghaggar river. In both the cores aeolian sediments are overlain by layers of fluvial sediments (Fig. 2b). The aeolian sediments in both the cores have OSL ages of $\sim 150 \mathrm{ka}$. On the other hand, the OSL ages of fluvial sediments in GS -10 and GS -11 cores show a range of about $>71$ to 6.4 ka and $>68$ to 7.2 ka (Fig. 2b), respectively. Sediment samples were collected systematically at regular intervals from each distinct depositional layers present in the cores. Detailed lithology of the samples is provided in Supplementary Tables 1 and 2. Sampling scheme is also shown in Fig. 2 b.

About $30-50 \mathrm{~g}$ of bulk sediment $(n=38)$ was collected from each sediment layer, labelled, 
and packed in air-tight sample bags until subsequent chemical work. A total of 27 carbonate nodules were collected, wherever they dominantly occurred, from the fluvial and aeolian deposits in both the cores. Note that nodules were predominantly found only at depths $\sim 7-16 \mathrm{~m}(<12$ to $>23 \mathrm{ka})$ and $\sim 24$ to $32 \mathrm{~m}(\sim 59$ to $>71 \mathrm{ka})$ in the GS-10 core corresponding to MIS2 and MIS4 glacial periods (MIS: marine isotope stage), and at depths $\sim 14-20 \mathrm{~m}$ ( $\sim 77$ to $\sim 62 \mathrm{ka})$ in GS -11 corresponding to MIS3 interglacial period (Fig. 2b). Carbonate nodules hosted in fluvial deposits range in size between 0.5 and $2 \mathrm{~cm}$ and were mostly scattered within finer channel sands. On the other hand, carbonate nodules hosted in the aeolian sediments ( $>37 \mathrm{~m}$ depth, $\geq 150 \mathrm{ka}$ ) underlying the fluvial deposits were mainly composed of fine sediment aggregates held together by calcareous cement. The bulk sediment samples were oven-dried at $\sim 80-90{ }^{\circ} \mathrm{C}$ for $\sim 24 \mathrm{~h}$ and then grounded to $<100 \mu \mathrm{m}$ size using an agate cup-mill (FRITSCH Pulverisette 9), which were later used for elemental and isotope analyses.

\subsection{Major and trace elements analysis}

A total of 35 samples, 17 from GS-11 and 18 from the GS-10 core, were analysed for major and selected trace element concentrations in the carbonate-free (treated with $0.6 \mathrm{~N} \mathrm{HCl}$ at $60-70{ }^{\circ} \mathrm{C}$ for about $2 \mathrm{~h}$ ) bulk sediments. Homogenized samples were pressed at 20 tons using a hydraulic press to prepare pellets of $30 \mathrm{~mm}$ diameter and $5 \mathrm{~mm}$ thickness. These pellets were analyzed using a Rigaku ZSX Primus II wave length dispersive X-ray fluorescence spectrometer (WD-XRF) having a $4 \mathrm{~kW}$ $\mathrm{Rh}$ target and operated at $60 \mathrm{KV}$ and $50 \mathrm{~mA}$, at the Indian Institute of Technology Kanpur (IITK). Several international rock, soil, and sediment standards (USGS, Canadian Certified Reference Material Project: CCRMP, International atomic energy agency) were used for calibration. The accuracy of measurements was monitored using the stream sediment (STSD-4) and soil (TILL-3) standards from CCRMP. The expected and measured values for the soil and sediment standard samples are given in Supplementary Tables 3 and 5.

\subsection{Radiogenic Sr and Nd isotopic analysis}

$\mathrm{Sr}$ and $\mathrm{Nd}$ isotopic compositions were measured on (carbonate and organic matter free) bulk silicate fractions of the sediments. About $1 \mathrm{~g}$ of powdered sample was treated with $0.6 \mathrm{~N} \mathrm{HCl}$ at $60-70$ ${ }^{\circ} \mathrm{C}$ for $30 \mathrm{~min}$ in an ultrasonic bath. The carbonate-free samples were heated at $\sim 600{ }^{\circ} \mathrm{C}$ for $8 \mathrm{~h}$ to 
remove organic matter. Subsequently, $\sim 0.1 \mathrm{~g}$ of this was transferred to Savillex ${ }^{\circledR}$ vials and digested with acids $\left(2 \mathrm{~mL}\right.$ of $\mathrm{HNO}_{3}+1 \mathrm{~mL}$ of $\left.\mathrm{HF}\right)$ at $100{ }^{\circ} \mathrm{C}$ for $24 \mathrm{~h}$, dried. About $3 \mathrm{~mL}$ of aqua regia was added to the dried sample and sealed vials were heated at $110{ }^{\circ} \mathrm{C}$ for $\sim 12 \mathrm{~h}$. After addition of $3 \mathrm{~mL}$ of $2 \mathrm{~N} \mathrm{HCl}$ in steps, the vials were kept at $110^{\circ} \mathrm{C}$ for drying, following which the samples were ready for ion exchange column chemistry. Standard ion exchange protocols (Singh et al., 2008) were followed for separation of pure $\mathrm{Sr}$ and $\mathrm{Nd}$ fractions. The ${ }^{87} \mathrm{Sr} /{ }^{86} \mathrm{Sr}$ and ${ }^{143} \mathrm{Nd} /{ }^{144} \mathrm{Nd}$ ratios were measured on a Finnigan Neptune multi-collector Inductively Coupled Plasma Mass Spectrometer (MC-ICP-MS) at the Physical Research Laboratory, Ahmedabad, India. Mass fractionation corrections for $\mathrm{Sr}$ and $\mathrm{Nd}$ were made by normalizing ${ }^{86} \mathrm{Sr} /{ }^{88} \mathrm{Sr}$ to 0.1194 and ${ }^{146} \mathrm{Nd} /{ }^{144} \mathrm{Nd}$ to 0.7219 , respectively. Repeated analyses of NBS987 $\mathrm{Sr}$ standard yielded ${ }^{87} \mathrm{Sr} /{ }^{86} \mathrm{Sr}$ values of $0.710287 \pm 0.000020(1 \sigma, \mathrm{n}=15)$. For $\mathrm{Nd}$, JMC-321 standard was measured that yielded an average ${ }^{143} \mathrm{Nd} /{ }^{144} \mathrm{Nd}$ of $0.511095 \pm 0.000007(1 \sigma, \mathrm{n}$ =13). The Sr and Nd content in procedural blanks were found to be several orders of magnitude lower than the sample concentrations and therefore no blank corrections were done. Details on $\mathrm{Sr}$ and $\mathrm{Nd}$ analyses can also be found in Goswami et al. (2012).

\subsection{Petrography of carbonate nodules}

For micromorphological studies, thin sections of carbonate nodules were prepared and examined under both plane- and cross-polarised light at variable magnification of 20-40X using a Nikon Eclipse E200 microscope. Further, standard thick sections of nodules were studied using a scanning electron microscope (SEM) at IITK. High resolution imaging and semi-quantitative compositional analyses of all the polished and gold coated samples were done using a Carl Zeiss EVO 50 SEM coupled with an energy dispersive spectrometer (EDS, INCA PENTA FET X3), operated at $20 \mathrm{KV}$, at IITK.

\subsection{Stable oxygen and carbon isotopic analyses}

Stable oxygen and carbon isotope ratios in 27 carbonate nodules (14 from fluvial and 13 from aeolian sediments) were obtained using a Thermo Finnigan MAT253 isotope ratio mass spectrometer coupled online with a Gas Bench II sample preparation device, at the Department of Earth Sciences, University of Cambridge, UK. Bulk carbonate powdered samples were reacted with $100 \% \mathrm{H}_{3} \mathrm{PO}_{4}$ at 
$50^{\circ} \mathrm{C}$, and the $\mathrm{CO}_{2}$ released was subsequently analyzed for ${ }^{18} \mathrm{O} /{ }^{16} \mathrm{O}$ and ${ }^{13} \mathrm{C} /{ }^{12} \mathrm{C}$ isotopic ratios. All isotopic measurements are reported in the standard $\delta$ notation $\left(\delta^{18} \mathrm{O}\right.$ and $\delta^{13} \mathrm{C}$ in VPDB scale), defined as the relative difference in parts per thousand (\%o, per mil) between the isotope ratio of the sample $\left({ }^{18} \mathrm{O} /{ }^{16} \mathrm{O}\right.$ and $\left.{ }^{13} \mathrm{C} /{ }^{12} \mathrm{C}\right)$ and that in the reference standard. Analytical precision, based on repetitive analyses of the Carrara Marble standard, was $\pm 0.1 \%$ for both.

The $\delta^{13} \mathrm{C}$ analyses of bulk sediment organic matter in 24 samples, 14 from GS-10 and 10 from GS-11 core, were performed at the Stable Isotope Laboratory of the Indian Institute of Technology, Kanpur, India. Prior to isotopic analyses, $\sim 2 \mathrm{~g}$ of bulk sediment powder was treated with $0.5 \mathrm{~N} \mathrm{HCl}$ at room temperature for $2 \mathrm{~h}$ to remove the carbonate fraction, and centrifuged with milliQ water to remove any remaining acid/soluble salts. For isotopic measurement, $\sim 50 \mathrm{mg}$ of decarbonated sediment samples were combusted in a Flash 2000 elemental analyzer and the evolved $\mathrm{CO}_{2}$ was analyzed in a Delta V Plus mass spectrometer in continuous-flow mode. Data normalization was done using a calibration based on analyses of isotope reference standards NBS19, LSVEC, CH-6 (Sucrose) supplied by IAEA, while analytical precision was monitored by analyzing IAEA 601 (Benzoic acid; $\delta^{13} \mathrm{C}=$ $-28.8 \%$ ) standard along with the unknown samples. All $\delta^{13} \mathrm{C}$ values of sediment organic matter are reported in the VPDB scale with analytical precision of $\pm 0.15 \%$.

\section{Results}

\subsection{Elemental geochemistry of bulk silicates}

The concentrations of major oxides (wt \%) and selected trace elements (ppm) in the carbonatefree core sediments are provided in the Supplementary Tables 3 to 6). All the major element data were normalized to $100 \%$ on an anhydrous basis and used in the relevant figures here. Fig. 3 shows the range of variations in major oxides against $\mathrm{Al}_{2} \mathrm{O}_{3}$ in the GS core sediments. The $\mathrm{Al}_{2} \mathrm{O}_{3}$ content in the GS sediments shows a strong negative correlation $\left(\mathrm{r}^{2}=0.96\right)$ with $\mathrm{SiO}_{2}$, and positive correlations with $\mathrm{Fe}_{2} \mathrm{O}_{3}\left(\mathrm{r}^{2}=0.85\right), \mathrm{K}_{2} \mathrm{O}\left(\mathrm{r}^{2}=0.82\right), \mathrm{MgO}\left(\mathrm{r}^{2}=0.93\right)$ and $\mathrm{TiO}_{2}\left(\mathrm{r}^{2}=0.87\right)$. The GS-10 sediments form two clusters; one with high $\mathrm{SiO}_{2}$ and low $\mathrm{Al}_{2} \mathrm{O}_{3}$ representing coarser sand, and the other with low $\mathrm{SiO}_{2}$ and high $\mathrm{Al}_{2} \mathrm{O}_{3}$ representing finer floodplain (silt/clay) sediments from the top $6 \mathrm{~m}$ depth. On the other hand, GS-11 core comprises of mainly fine sand with minor coarse sand (Fig. 2b; Supplementary 
Table 1), and hence show less variability in major oxides compared to that of the GS-10 core. These observations show the effect of grain size on partitioning of major oxide abundances in the alluvial sediments from our study area.

The chemical index of alteration (CIA) has been widely used as a weathering index to quantitatively evaluate the intensity of chemical weathering in drainage basins ( $\mathrm{Li}$ and Yang, 2010). Following Nesbitt and Young (1982), the CIA value is calculated as:

$$
C I A=\frac{\mathrm{Al}_{2} \mathrm{O}_{3}}{\mathrm{Al}_{2} \mathrm{O}_{3}+\mathrm{CaO}^{*}+\mathrm{Na}_{2} \mathrm{O}+\mathrm{K}_{2} \mathrm{O}} \times 100 \text { (molar) } \quad \text { Equation (1) }
$$

where $\mathrm{CaO}^{*}$ represents only the silicate fractions. Typically, the CIA value in unweathered upper crust and unaltered plagioclase and $\mathrm{K}$-feldspars is $\sim 50$, in average shale is $\sim 70-75$, which increases up to 100 for highly weathered residual soils. Generally, the CIA value of 50 is indicative of first-cycled sediments and increases with increasing degree of chemical weathering (Nesbitt and Young, 1982). The CIA values of GS sediments (46-70: Supplementary Table 3 and 4) suggest weak to intermediate chemical weathering at the source.

Fig. 4 shows the composition of GS sediments in the $\mathrm{Al}_{2} \mathrm{O}_{3}-\mathrm{CaO}+\mathrm{Na}_{2} \mathrm{O}-\mathrm{K}_{2} \mathrm{O}$ ternary plot of Nesbitt and Young (1982). The average upper continental crust (UCC, Rudnick and Gao, 2003) has CIA of 51 and plots towards the plagioclase side on the feldspar line. The average compositions of global river sediments plot in the zone of intermediate weathering. Most of the GS sediments as well as modern (Himalayan) river sediments plot in the zone of weak weathering along the line between UCC and world rivers. The weathering trend is parallel to the A-CN line, which can be attributed to the relatively higher mobility of $\mathrm{Na}$ and $\mathrm{Ca}$ during weathering compared to the less mobile $\mathrm{Al}$ and retention of $\mathrm{K}$ onto the clay minerals.

\subsection{Sr-Nd isotope compositions of bulk silicates in drill core sediments}

The ${ }^{87} \mathrm{Sr} /{ }^{86} \mathrm{Sr}$ and ${ }^{143} \mathrm{Nd} /{ }^{144} \mathrm{Nd}$ isotopic ratios in bulk sediments of cores are given in Table 1. The ${ }^{87} \mathrm{Sr} /{ }^{86} \mathrm{Sr}$ and ${ }^{143} \mathrm{Nd} /{ }^{144} \mathrm{Nd}$ ratios in the core sediments range between 0.7365 and 0.7783 , and 0.511881 and $0.511655\left(\varepsilon_{\mathrm{Nd}}:-14.6\right.$ to -19.0$)$, respectively. Several authors have highlighted the effect of grain size sorting during fluvial transport of sediments that may lead to mineral sorting between bedload and suspended sediments, and in turn influence the geochemistry of the bulk transported 
sediments (Singh and France-Lanord, 2002; Garzanti et al., 2010; Lupker et al., 2011 and 2013; Garçon et al., 2013 and 2014; Garçon and Chauvel, 2014). Variation plots of ${ }^{87} \mathrm{Sr} /{ }^{86} \mathrm{Sr}$ and $\varepsilon_{\mathrm{Nd}}$ versus $\mathrm{Al}_{2} \mathrm{O}_{3} / \mathrm{SiO}_{2}$ which is a proxy for grain size (Lupker et al., 2011) show random scatter and lack of a correlation in the GS core sediments (Fig. 5a, b). Further, for a given $\mathrm{Al}_{2} \mathrm{O}_{3} / \mathrm{SiO}_{2}$ ratio, considerable variations are observed in both the $\mathrm{Sr}$ and $\mathrm{Nd}$ (e.g., $3 \varepsilon$ units) isotopic ratios. These suggest that mineral sorting during transport had minimal effect on the isotopic ratios. Similarly, plots of ${ }^{87} \mathrm{Sr} /{ }^{86} \mathrm{Sr}$ versus $\mathrm{Rb} / \mathrm{Sr}$ and $\varepsilon_{\mathrm{Nd}}$ versus $\mathrm{Sm} / \mathrm{Nd}$ (Fig. 5c, d) show high scatter indicating negligible effect of mineral sorting on the isotopic ratios. To evaluate the effect of mineral sorting on the geochemical variability of fluvially-transport sediments, Garçon et al. (2013) and Garçon and Chauvel (2014) analyzed the $\mathrm{Sr}, \mathrm{Nd}$, and $\mathrm{Hf}$ isotopic composition of bedloads, suspended loads and individual minerals in the sediments transported by the Ganges river and its tributaries. Their results showed no systematic change in the $\mathrm{Nd}$ isotopic ratios as a function of $\mathrm{Al}_{2} \mathrm{O}_{3} / \mathrm{SiO}_{2}$ (grain size proxy) indicating negligible effect of sorting on the $\mathrm{Nd}$ isotopes. These authors concluded that the $\mathrm{Nd}$ isotopic composition of fluvial sediments is certainly a robust proxy for source composition. Although, mineral sorting may affect the $\mathrm{Sr}$ isotopic fractionation, nevertheless the ${ }^{87} \mathrm{Sr} /{ }^{86} \mathrm{Sr}$ ratios can also be used as a proxy for provenance if the composition of sources are isotopically distinct as for the Himalayan endmember sources (Garçon and Chauvel, 2014). Other studies have also argued that both $\mathrm{Sr}$ and $\mathrm{Nd}$ isotopic compositions of sediments are not affected by sorting during fluvial transort (e.g., Singh et al., 2009; Lupker et al., 2013). Because the two major Himalayan lithotectonic units, the Higher and Lesser Himalaya, are characterized with distinct $\mathrm{Sr}-\mathrm{Nd}$ isotopic compositions (Fig. 6), the temporal variations of ${ }^{87} \mathrm{Sr} /{ }^{86} \mathrm{Sr}$ and $\varepsilon_{\mathrm{Nd}}$ (by $4.4 \varepsilon$ units) in our alluvial sediments can be used to infer temporal changes in the sediment supply from the two major Himalyan sources.

In the ${ }^{87} \mathrm{Sr} /{ }^{86} \mathrm{Sr}-{ }^{143} \mathrm{Nd} /{ }^{144} \mathrm{Nd}$ isotopic space (Fig. 6), distinct fields define the composition of two major Himalayan lithotectonic units. Typically, the Lesser Himalayan (LH) rocks have high ${ }^{87} \mathrm{Sr} /{ }^{86} \mathrm{Sr}$ ratio $(0.85 \pm 0.09$ vs. $0.76 \pm 0.03)$ and low $\varepsilon_{\mathrm{Nd}}(-24.4 \pm 0.9$ vs. $-15.0 \pm 1.4)$ values compared to that in the Higher Himalayan (HH) rocks (Najman et al., 2006; Rahaman et al., 2009). The Sr and $\mathrm{Nd}$ isotopic ratios in the GS-11 core as well as the modern Sutlej sediments are broadly within the range reported for the $\mathrm{HH}$ and $\mathrm{LH}$ units, with more affinity for the HH rocks. Compared to the Ganga- 
Yamuna interfluve sediments from the IITK core (Rahaman et al., 2009), the GS-11 core sediments show higher ${ }^{87} \mathrm{Sr} /{ }^{86} \mathrm{Sr}$ and lower $\varepsilon_{\mathrm{Nd}}$ values. Note that one sample from $35.4 \mathrm{~m}$ depth is compositionally similar to the Ghaggar/Thar Desert sediments (Fig. 6). This sample belongs to floodplain facies characterized by overbank deposition of yellow mud during MIS5, overlying the aeolian sand deposits in the core (Fig. 2b). It is likely that this sample has some contribution from the aeolian-reworked fine sand.

\subsection{Petrography of carbonate nodules}

Carbonate nodules occurred mostly as scattered mass in the host sediments. Morphologically, the GS nodules are sub-angular to sub-rounded, light cream to white colored, and range in size between $5-15 \mathrm{~mm}$. These nodules mainly comprise of silt and mud-sized silicates held together by calcareous cement. Thin section studies reveal dominantly spary to micrite calcite groundmass embedding subhedral to anhedral detrital grains of quartz, feldspar, mica, and lithic fragments (Fig. 7). Two types of nodules are observed based on the groundmass to clast ratio: viz. light colored nodules comprising relatively bigger clasts in micritic groundmass and dark-brown colored ones comprising relatively smaller clasts (Fig. 7a). Clasts mostly consist of subhedral quartz, feldspar (lath-shaped), and needle shaped muscovite and biotite (Fig. 7b-f). The relatively bigger grains in micritic groundmass show typical floating grain texture with openings filled with microspar (Fig. 7c, d). Grain boundaries with corona texture indicating neomorphic growth of spar is visible in Fig. 7e and $\mathrm{f}$. Further, X-ray diffraction patterns (not shown here) of selected nodules revealed calcite to be the dominant phase. The presence of homogeneous micritic calcite is a clear indication of minimal recrystallization (Driese and Mora, 1993), which is more likely to preserve the primary isotopic imprint.

The alpha fabrics (Wright and Tucker, 1991) of carbonate nodules in the GS cores are characterized by the presence of micritic $(<5 \mu \mathrm{m})$ to microsparitic $(<5-15 \mu \mathrm{m})$ groundmass, floating detrital grains in the micritic matrix, microsparitic re-entrants on detrital quartz grains, and presence of organic matter. It suggests that nodules were formed under drier climate (notable abiotic alpha fabric). Features indicating secondary nature of carbonates, particularly beta fabric features associated 
with biological activity, such as alveolar fabric, needle fibre and microbial calcite tubes (Wright and Tucker, 1991), were not found in any of the studied samples. It can be concluded that GS nodules have undergone negligible secondary alteration/diagenesis. Further, SEM images (Fig. 8) of selected GS nodules also show dominance of micritic to microsparitic matrix embedding quartz and mica grains. The mineral grains are corroded or partially replaced by calcite. The interstitial voids are rounded to tubular partially filled with spary calcite. Absence of clay, gypsum, and pedogenic features like rootlets or root traces in these cores suggest no dominant soil formation activities have occurred. Other studies also showed dominant alpha fabrics in carbonates formed in the semi-arid Thar Desert during the Late Pleistocene (Andrews et al., 1998) and Late Quaternary (Dhir et al., 2004). Generally, carbonate nodules in the Quaternary deposits from northern and western India are characterized by an alpha fabric (Sinha et al., 2006b); these regions have a present-day rainfall of 200 to $1000 \mathrm{~mm} / \mathrm{yr}$.

\subsection{Stable carbon and oxygen isotope composition}

The $\delta^{18} \mathrm{O}$ and $\delta^{13} \mathrm{C}$ values in the carbonate nodules from GS-10 and GS-11 cores are given in Table 2 and shown in Fig. 9. The ranges of $\delta^{18} \mathrm{O}$ variability in GS-10 (-8.67 to $-6.18 \%$ ) and GS-11 $\left(-8.2\right.$ to $-5.2 \%$ ) nodules are $-3.3 \%$ and $2.9 \%$, respectively. The ranges of $\delta^{13} \mathrm{C}$ variability in GS-10 $(-4.12$ to $1.24 \%$ o) and GS $-11(-3.5$ to $1.05 \%$ o) nodules are $~ 5.4 \%$ and $4.5 \%$, respectively. The average $\delta^{18} \mathrm{O}$ of nodules in both the GS cores $\left(\delta^{18} \mathrm{O}_{\mathrm{GS}}=-7.16 \% \pm 0.70 \%\right)$ is distinctly lower than that of the mid-Pleistocene to Holocene aeolian calcretes $\left(\delta^{18} \mathrm{O}_{\text {aeolian }}=-4.99 \% \pm 1.04\right)$ from the Thar Desert and nearby area (Dhir et al., 2004; Andrews et al., 1998). Similarly, the average $\delta^{13} \mathrm{C}$ value in the GS core $\left(\delta^{13} \mathrm{C}_{\mathrm{GS}}=-1.50 \%\right.$ ) is lower than that in the aeolian nodules $\left(\delta^{13} \mathrm{C}_{\text {aeolian }}=-0.29 \%\right.$ ) from the Thar Desert (Dhir et al., 2004; Andrews et al., 1998). Further, the $\delta^{18} \mathrm{O}$ and $\delta^{13} \mathrm{C}$ values of carbonates from the GS cores are comparable to that of the pedogenic carbonates of similar age from the Ganga interfluves (Srivastava, 2001; Rahaman et al., 2011), albeit minor differences (Fig. 9b). However, isotopic compositions of GS nodules are distinctly different from the pedogenic carbonates in the Pleistocene paleosol sequences in the Bengal Basin (Alam et al., 1997). The pedogenic carbonates from Bangladesh plot in two distinct fields, which Alam et al. (1997) attributed to variability in temperature and rapid change from humid (leading to lower isotopic values) to 
arid/semi-arid (higher isotopic values) climate. The pedogenic carbonates from the eastern (Srivastava, 2001) and the southern (Rahaman et al., 2011) Ganga Plains show scatter with variations in $\delta^{18} \mathrm{O}$ value of $\sim 4.4 \%$ and $\sim 3 \%$, respectively, which was attributed to climatic variations for the past $\sim 100 \mathrm{ka}$.

Stable carbon isotope compositions of bulk organic matter $\left(\delta^{13} \mathrm{C}_{\mathrm{SOM}}\right)$ in the GS core sediments are given in Table 3. The $\delta^{13} \mathrm{C}_{\text {SOM }}$ values vary little in the individual cores; from -23.2 to $-27.4 \%$ in GS-10 and from -23.9 to $-25.5 \%$ in GS-11 core, with an overall variability of $4.2 \%$ during the past $\sim 75 \mathrm{ka}$. This suggests that the dominant vegetation during this time period was mainly $\mathrm{C}_{3}$ plants. For comparison, $\delta^{13} \mathrm{C}$ of organic carbon in the Bengal Fan sediments, used as a proxy for vegetation in the Himalayan basin, varied from $-19 \%$ to $-22.5 \%$ during the interval from 19,000 to 363 cal yr BP (Galy et al., 2008b).

\section{Discussion}

\subsection{Inferences on fluvial depositional settings}

Integration of resistivity data and drill cores has provided important insights for fluvial stratigraphy and depositional settings. The stratigraphic architecture reconstructed by Sinha et al. (2013), based on the resistivity data along the same transect on which the cores GS 10 and 11 lie, suggested changes in the fluvial setting from that of a wide-channel braided river system (high energy) to an incised channel system, and subsequently to a narrow-channel seasonal river system. These conclusions also agree with our interpretations derived from the GS-10 and GS-11 lithologs; detailed sedimentology and stratigraphy of these two cores along with other studied cores (not presented here) from the same transect across the paleochannel will be presented elsewhere (Singh et al., manuscript under prep.). The GS-10 core litholog (Fig. 2b) shows high energy channel deposits of coarse- and medium-grained sand bodies overlain by relatively low energy channel deposits of finegrained sand bodies, which are further overlain by floodplain sediments deposited by the modern Ghaggar river. These fine-grained floodplain sediments represent reworked sediments from the adjacent older floodplain deposits. The GS-11 core lithology also shows high-energy channel deposits of coarse-grained sand overlain by relatively low-energy flow regime deposits represented by 
interlayering of fine sand and silt bodies, which at the top are covered by a thin veneer of modern floodplain fines (Fig. 2b).

These different deposits represent different fluvial depositional settings, which can be interpreted in terms of fluvial landform evolution in the study area. Interestingly, these different deposits from the two cores show variable CIA values (Fig. 4; Supplementary Table A.3 and A.4) that may be related to differences in the residence and exposure times of the sediments associated with different depositional settings in a fluvial environment. Singh (2009) compared CIA values of sediments from the upper reaches of Ganga river (av. CIA 50) with that of the bed load sediments in the plains (av. CIA 60). He concluded that the upper reach sediments represent immature products of the source rocks formed mainly by physical weathering, and after entering the plains these immature sediments have undergone weak chemical weathering. It is possible that sediments undergo variable degrees of chemical weathering, to some extent, during fluvial aggradation processes. Floodplain sediments are exposed to surface processes for relatively longer periods until they are covered with new sediments during subsequent flooding. This may result in floodplain sediments undergoing relatively more weathering compared to channel sediments.

Fig. 4 shows that most of the Himalayan modern river sediments plot in the zone of weak weathering (CIA: 55 to 65), except the modern Ghaggar sediments that show intermediate weathering $($ CIA $=69)$. Further, two clusters for the GS-10 sediments can be observed in Fig. 4; one in the zone of weak weathering represented by high energy channel deposits of medium to coarse sand from deeper part of the core, and the other in the zone of intermediate weathering represented by finer silty/clayey floodplain deposits from shallow depths. The GS-11 core sediments mainly represent channel sands interlayered with thin layers of floodplain deposits (Fig. 2b), which plot in the zone of weak weathering. A general observation from the A-CN-K plot is that the GS core sediments form an array with lower CIA values for channel sands, intermediate for channel and floodplains interlayer deposits, and higher for finer deposits that are similar to the modern Ghaggar sediments. Further, the younger sediments ( 12 ka) from shallow depths in the GS-10 core (Fig. 2b) have relatively higher CIA values similar to that of the modern Ghaggar river sediments. In addition, these younger sediments are texturally similar to the modern Ghaggar sand. The main source of sediments in the 
modern Ghaggar river, at the GS core locations, is from reworked floodplain sediments, with minor contribution from upstream sediments. On the other hand, the deeper channel sands are texturally similar (with similar CIA values) to other major Himalayan rivers such as the Sutlej, Ganga, and Yamuna. This suggests the possibility that the older GS sediments were brought down to the core sites by a large river system originating in the Himalaya, which were overlain in recent times by the finer sediments deposited by the present-day Ghaggar river. This is consistent with the observation that the Ghaggar is a foothills-fed river, which cannot deposit such thick fluvial-sand bodies (Fig. 2b) in the buried channel.

\subsection{Variation in sediment provenance due to hinterland climate variability}

The $\mathrm{Sr}-\mathrm{Nd}$ isotope composition of sediments has been used as a provenance indicator (Tripathi et al., 2004; Najman, 2006; Singh et al., 2008; Rahaman et al., 2009; Galy et al., 2010) with a priori assumption that isotopic composition of different sources are distinct and also remains unaffected during the processes of sediment production, transportation, and deposition. Derry and France-Lanord (1996) suggested that isotopic composition might be modified due to the formation of secondary clay minerals during weathering. However, this effect is negligible if clay mineral content in the sediments is very low to cause any significant modification of the source isotopic composition (Singh and France-Lanord, 2002). Therefore, alluvial sediments are likely to retain the isotopic signature $\left({ }^{87} \mathrm{Sr} /{ }^{86} \mathrm{Sr}\right.$ and ${ }^{144} \mathrm{Nd} /{ }^{143} \mathrm{Nd}$ ratios) of source rocks in the catchment viz. hinterland Himalaya. Additionally, we have argued earlier (Section 3.2) that grain size or mineral sorting has not affected the $\mathrm{Sr}-\mathrm{Nd}$ isotopic composition of GS core sediments (Fig. 5).

The GS core sites are located on the trace of the buried channel of a large river system presumably sourced in the Himalayan hinterland. Sr and Nd isotopic ratios in the GS cores are broadly within the range reported for $\mathrm{HH}$ and $\mathrm{LH}$ tectonic units with more affinity for the $\mathrm{HH}$ rocks (Fig. 6). In contrast, Tripathi et al. (2004) identified non-glaciated Sub-Himalaya as the source to paleo-Ghaggar river sediments. Based on a few Sr-Nd isotope ratios (Ghaggar sediments in Fig. 6) in the sediments from a 9-m vertical profile (representing 2 to $20 \mathrm{ka}$ ) from the western Indo-Gangetic plains, Tripathi et al. (2004) argued that these sediments were derived from Sub-Himalayan Tertiary sediments; 
deeper sediments in their section were derived from early Paleogene Subathu Formation, whereas shallower sediments were derived from Siwalik, Dagshai, and Kasauli Formations in the SubHimalaya (Fig. 2a). However, we have argued earlier in section 4.1 that these buried sands were deposited by a river system originating in the $\mathrm{HH}$.

Rahaman et al. (2009) argued that major climatic shifts in the hinterland Himalaya can affect sediment contributions from isotopically distinct endmembers (mainly $\mathrm{HH}$ and $\mathrm{LH}$ ), which should be reflected in the isotopic composition of the sediment mixture. However, unlike the Central Himalayas, NW Himalaya show more complex geometries (Myrow et al., 2015 and references therein), and therefore isotopic composition of different bedrock domains exposed in the Sutlej catchment may affect the composition of the sediment mixture. In NW (Garhwal) Himalaya, two tectonic divisions of LH are identified as "outer LH" (oLH) on the hanging wall and "inner LH" (iLH) on the footwall of the Tons thrust (Valdiya, 1980). Exhumation related erosional activity has removed parts of oLH resulting in exposure of mostly iLH rocks in the NW Himalaya (Fig. 2a; also see Fig. 1 of Myrow et al., 2015). Richards et al. (2005) have reported Sr-Nd isotopic composition of rocks from key tectonostratigraphic units in the Sutlej valley, which shows iLH is isotopically distinct (and plot in the LH field in Fig. 6) from that of the oLH and HH, with significant overlap between oLH and HH. Nevertheless, the $\mathrm{HH}$ rocks north of the Main Central Thrust lie at higher topographic elevations whereas the LH rocks are exposed down to relatively lower elevations near the Main Boundary Thrust (MBT). We hypothesize that the Sr-Nd isotopic composition of our core sediments strongly depends on variable sediment mixing from $\mathrm{HH}$ and iLH during different glacial-interglacial cycles. In other words, variation in sediment provenance can be linked to variation in glacial cover over the $\mathrm{HH}$ extending down to some part of iLH at a higher elevation. Henceforth, iLH source is simply referred as LH unless otherwise mentioned. Down-core variations in ${ }^{87} \mathrm{Sr} /{ }^{86} \mathrm{Sr}$ and $\varepsilon_{\mathrm{Nd}}$ of GS sediments (Fig. 10a, b) are comparable with those reported for the Ganga interfluve sediments (Rahaman et al., 2009), albeit minor differences: (1) although the temporal trends are similar, absolute values differ, and (2) similar ${ }^{87} \mathrm{Sr} /{ }^{86} \mathrm{Sr}$ ratios, but large differences in terms of $\varepsilon_{\mathrm{Nd}}$. Between late MIS5 and MIS4 ${ }^{87} \mathrm{Sr} /{ }^{86} \mathrm{Sr}$ ratio in the GS sediments increases from 0.7365 to 0.7783 and $\varepsilon_{\mathrm{Nd}}$ decreases from -15.6 to -19.0 . Subsequently, the ${ }^{87} \mathrm{Sr} /{ }^{86} \mathrm{Sr}$ ratio decreases to 0.7574 and $\varepsilon_{\mathrm{Nd}}$ increases to -18.0 at the MIS4 and MIS3 
transition. A distinct positive ${ }^{87} \mathrm{Sr} /{ }^{86} \mathrm{Sr}$ excursion (and negative $\varepsilon_{\mathrm{Nd}}$ ) is observed during the MIS4 glacial stage, similar to that observed in the Ganga interfluve sediments reported by Rahaman et al. (2009). During late MIS3, the ${ }^{87} \mathrm{Sr} /{ }^{86} \mathrm{Sr}$ ratio in the GS sediments further decreases to 0.7498 and $\varepsilon_{\mathrm{Nd}}$ increases to -17.1 . During the transition from MIS2 ( 21 to $17 \mathrm{ka}$ ) to MIS1 (up to 6-4 ka), the ${ }^{87} \mathrm{Sr} /{ }^{86} \mathrm{Sr}$ ratio of the GS sediments shows a decreasing trend while the $\varepsilon_{\mathrm{Nd}}$ increases from -16.6 to -14.6. The distinctly high ${ }^{87} \mathrm{Sr} /{ }^{86} \mathrm{Sr}$ and low $\varepsilon_{\mathrm{Nd}}$ in the GS core observed during the glacial periods suggest increasing sediment contributions from the LH source (high ${ }^{87} \mathrm{Sr} /{ }^{86} \mathrm{Sr}$ and low $\varepsilon_{\mathrm{Nd}}$ ). The glacial periods also coincide with periods of less intense monsoon precipitation reflected in $\Delta \mathrm{P} \%$ (Fig. 10f: Prell and Kutzbach, 1987) and reduced solar insolation (Clemens et al., 1991). It is possible that during MIS4 ( 70 ka) and MIS2 ( 20 ka) extensive glacial cover over the HH (Owen et al., 2002) led to decreasing sediment contribution from this endmember source and increasing contribution from the relatively more exposed LH source. On the other hand, warmer MIS3 and MIS1 interglacial periods resulted in relatively less glacial cover over the $\mathrm{HH}$ exposing more sediments of this endmember, which were readily available for erosion and transportation. This scenario coupled with higher monsoon precipitation during the interglacial periods probably resulted in an increasing sediment contribution from the $\mathrm{HH}$ that is reflected by the low ${ }^{87} \mathrm{Sr} /{ }^{86} \mathrm{Sr}$ and high $\varepsilon_{\mathrm{Nd}}$ values of the sediment mixture. Similar conclusions were also drawn by Rahaman et al. (2009) from the study of the Ganga Plains sediments, strongly supporting a climate-erosion link. It is interesting to note that ${ }^{87} \mathrm{Sr} /{ }^{86} \mathrm{Sr}$ ratio in the GS core was higher and $\varepsilon_{\mathrm{Nd}}$ was lower during MIS4 relative to that during MIS2 (Fig. 10a, b). This suggests a relatively smaller contribution of HH sediments during MIS4 relative to MIS2, indicating comparatively extensive glacial cover over the HH during MIS4. This indicates a relatively colder (and arid) climate during MIS4 relative to MIS2. Isotopic variability in the Guliya ice core from Tibet (Thompson et al., 1997) shows that $\delta^{18} \mathrm{O}_{\text {ice }}$ during MIS4 was slightly lower than that in the MIS2, suggesting a relatively colder MIS4 glacial period, which agrees with our interpretation. We conclude that the $\mathrm{Sr}-\mathrm{Nd}$ isotope compositions of Gangetic alluvial sediments reflect climatecontrolled sediment erosion in the catchment areas of hinterland Himalaya.

\subsection{Inferences on paleoclimate from stable isotope proxies}


Stable isotope ratios in pedogenic carbonates and paleosols have also been used as a reliable proxy for paleoclimate reconstruction (e.g., Cerling et al., 1989; Sheldon and Tabor, 2009 and references therein). As argued earlier, petrographic evidences suggest that GS carbonate nodules retained its primary isotopic signatures that can be used to infer the prevailing environmental conditions (climate and vegetation) at the time of nodule formation. Another objective of this work was to compare the isotopic variability to other available records from the NW India and the Ganga Plains.

In continental settings, carbonates form in equilibrium with water available in the environment, i.e., rainfall. The $\delta^{18} \mathrm{O}$ values of pedogenic carbonates have been used as a proxy for the $\delta^{18} \mathrm{O}$ value of local rainfall (e.g., Quade et al., 1989; Sinha et al., 2006b) and the temperature of carbonate precipitation, typically assumed to be the same as the mean annual temperature. The magnitude of the equilibrium oxygen isotope fractionation factor between carbonate and water is temperature dependent; as a result $\delta^{18} \mathrm{O}$ of carbonates increases by $\sim 0.20 \%$ to $0.23 \%$ per $1{ }^{\circ} \mathrm{C}$ decrease in temperature (Kim and O'Neil, 1997). In arid climates, evaporative enrichment in ${ }^{18} \mathrm{O}$ of rainfall can lead to increase in $\delta^{18} \mathrm{O}$ values of precipitating carbonates. Further, $\delta^{18} \mathrm{O}$ of rainfall is negatively correlated to the intensity of precipitation, the so called "amount effect" (Dansgaard, 1964; Rozanski et al., 1993), which is also observed for the present-day Indian monsoon precipitation (Sengupta and Sarkar, 2006; Kumar et al., 2010). Therefore, the amount effect may play a critical role in a monsoonal climate. However, the interpretations of ${ }^{18} \mathrm{O}$-variations in continental carbonates differ from those in the marine carbonates (Grootes, 1993). In the marine setting, decrease in temperature increases the $\delta^{18} \mathrm{O}$ value of the ocean and of the precipitating carbonates (ice-volume effect). On the other hand, decrease in mean annual surface temperature results in lower $\delta^{18} \mathrm{O}$ of rainfall in the continental setting, which in turn lowers the $\delta^{18} \mathrm{O}$ of precipitating carbonate (Dansgaard, 1964; Sharp, 2007). The $\delta^{18} \mathrm{O}$ of GS nodules from the alluvial sediments vary from -8.67 to $-6.18 \%$ (Table 2 ), which yields an estimated water (rainfall) composition of -6.1 to $-3.5 \%$ (VSMOW); using carbonate precipitation $\mathrm{T}$ of $25^{\circ} \mathrm{C}$ and Kim and O’Neil (1997) calcite-water fractionation at low temperatures [ $\Delta_{\text {Calcite-water }}=$ $18.03 \times\left(10^{3} / \mathrm{T}\right)-32.42$; all relative to VSMOW], and VSMOW-PDB conversion relation (Coplen et al., 1983: $\left.\delta^{18} \mathrm{O}_{\text {VSMOW }}=1.03092 \delta^{18} \mathrm{O}_{\mathrm{PDB}}+30.92\right)$. The estimated $\delta^{18} \mathrm{O}_{\mathrm{VSMOW}}$ of water is within the 
range of 40 years monthly weighted average precipitation in Delhi, India ( +0.9 to $-8.4 \%$; Sengupta and Sarkar, 2006). Because the temperature-dependent fractionation between calcite and water is of the order of $-0.23 \% /{ }^{\circ} \mathrm{C}$, a large temperature variation of $\sim 11{ }^{\circ} \mathrm{C}$ is needed to explain the $2.5 \%$ variability in $\delta^{18} \mathrm{O}$ of GS nodules. Therefore, it is concluded that temperature alone cannot explain the observed $\delta^{18} \mathrm{O}$ variability in the nodules.

In the $\delta^{13} \mathrm{C}$ vs. $\delta^{18} \mathrm{O}$ space (Fig. 9a), carbonates from NW India display two clusters, viz. more negative $\delta^{18} \mathrm{O}$ and $\delta^{13} \mathrm{C}$ value in carbonates hosted in the fluvial sediments of $\sim 75-13$ ka compared to those hosted in the aeolian sediments of $<70 \mathrm{ka}$ age reported by others. Because both the aeolian (Singhvi et al., 1996; Andrews et al., 1998; Dhir et al., 2004) and the alluvial carbonate nodules from the NW India have similar geologic age ranges, differences between their $\delta^{18} \mathrm{O}$ values cannot be explained solely by secondary evaporative enrichment of a common meteoric source in the same locality. It is possible that geomorphic setting may have primarily controlled the $\delta^{18} \mathrm{O}$ of available water. The lower $\delta^{18} \mathrm{O}$ in fluvial as opposed to the aeolian carbonates may be explained in terms of mixing of meteoric water with an isotopically-depleted water component; snow-melt originating from the Himalaya (such as the paleo-Sutlej) is a likely component. Whereas, meteoric precipitation in the aeolian setting, located away from this fluvial system, is least likely to be diluted by snow-melt water, which explains relatively higher $\delta^{18} \mathrm{O}$ of aeolian carbonates.

Fig. 10c and d shows variations in $\delta^{18} \mathrm{O}$ and $\delta^{13} \mathrm{C}$ values of carbonate nodules with respect to the depositional ages of the host sediments. Although, isotopic data from the GS nodules do not present a long-term and continuous trend, they do show similar isotopic variations $\left(\delta^{18} \mathrm{O} \sim 2.49 \%\right.$ and $\delta^{13} \mathrm{C} \sim 5.36 \%$ ) observed for the pedogenic carbonates from the Ganga interfluves (Rahaman et al., 2011). Note that carbonate nodules are not uniformly distributed throughout the GS cores, and dominantly occur in strata deposited during the MIS4 and MIS2 glacial stages that are marked by cold and arid climate characterized by less intense SW Indian Monsoon (Prell and Kutzbach, 1987). The $\delta^{18} \mathrm{O}$ of carbonates decreases by $\sim 2 \%$ between $\sim 73 \mathrm{ka}$ and $\sim 64 \mathrm{ka}$ during MIS4, followed by an increase of $\sim 2 \%$ towards $\sim 50$ ka during mid MIS3 interglacial. Similarly, $\delta^{18} \mathrm{O}$ decreases by $\sim 1.1 \%$ from $\sim 24$ to $\sim 15 \mathrm{ka}$, i.e., LGM to post-LGM period. In general, $\delta^{18} \mathrm{O}$ values of carbonates in the study area become more negative during glacial (clearly reflected in MIS4) and more positive during 
interglacial period. Interestingly, isotopic variations in the pedogenic carbonates from the eastern margin of Thar Desert also show similar increasing $\delta^{18} \mathrm{O}$ trend from glacial to interglacial transitions; $\delta^{18} \mathrm{O}$ carbonates belonging to colder MIS6 are $\sim 3 \%$ lower than that belonging to the warmer MIS5 period (see Fig. 6 of Achyuthan et al., 2007). Typically, variability in $\delta^{18} \mathrm{O}$ of pedogenic carbonates have been attributed to the rainfall "amount effect", which in turn is related to the intensity of SW summer monsoon; i.e., $\delta^{18} \mathrm{O}$ of rainfall during stronger/intense monsoon is lower than that during less intense monsoon. Modelled records of changes in the strength of SW Indian monsoon by Prell and Kutzbach (1987) show less intense monsoon precipitation during glacial stages and relatively higher intensity during interglacial stages; monsoon precipitation $(\Delta \mathrm{P} \%)$ decreases by $\sim 40 \%$ from Late MIS5 to MIS4, variable and higher precipitation during MIS3 relative to MIS4, a subsequent 20\% decrease during MIS2, followed by $\sim 30 \%$ increase during MIS1 interglacial (Fig. 10f). If the amount effect was the dominant factor, then $\delta^{18} \mathrm{O}$ of rainfall during MIS4 should be higher than that during MIS3, resulting in higher $\delta^{18} \mathrm{O}$ of precipitating carbonate during MIS4 compared to that in MIS3. However, exactly the opposite is observed in our data, which suggests that the amount effect may not be the principal factor controlling the $\delta^{18} \mathrm{O}$ of studied carbonates. The observed trend in our data may be explained by the near-linear positive relationship between the isotopic composition of precipitation and the mean annual surface temperature in continental settings (Dansgaard, 1964). This essentially suggests lower $\delta^{18} \mathrm{O}$ of precipitation during colder glacial times (and hence lower $\delta^{18} \mathrm{O}$ of precipitating carbonate) compared with higher $\delta^{18} \mathrm{O}$ of precipitation during warmer interglacial times, as a result of the combined effects of temperature dependent oxygen isotope fractionation between water vapor and condensate (inverse relation) and the fraction of vapor remaining in the air mass. Further, evaporative enrichment in ${ }^{18} \mathrm{O}$ of water in the study area, a relatively arid region in India, may have contributed to the slight increase in $\delta^{18} \mathrm{O}$ of carbonate observed during the early MIS3 interglacial.

The $\delta^{13} \mathrm{C}$ of carbonates vary within the range -4.12 to $1.24 \%$ (Table 2 ). $\delta^{13} \mathrm{C}$ values $\geq 0 \%$ o suggests that the GS carbonates precipitated in equilibrium with more inorganic carbon-rich water, as carbonates precipitating in equilibrium with organic carbon-rich water tend to have more negative $\delta^{13} \mathrm{C}$ values. We assume that carbonate precipitation occurred in equilibrium with water and DIC (dissolved inorganic carbon) with negligible contribution from soil organic carbon. The $\delta^{13} \mathrm{C}$ of 
carbonates during MIS4 is close to $0 \%$, which is $\sim 4 \%$ higher than that during the MIS3 (Fig. 10d). Similarly, $\delta^{13} \mathrm{C}$ values show a decreasing trend during the MIS2 glacial stage, reaching a value of $-4 \%$ around LGM. Because $\delta^{13} \mathrm{C}$ of carbonate is relatively insensitive to temperature $\left(\sim 0.035 \%\right.$ per $\left.{ }^{\circ} \mathrm{C}\right)$, observed isotopic variability in our data cannot be explained solely by temperature change. Further, there is very little ${ }^{13} \mathrm{C}-$ isotopic fractionation $\left(\sim+1 \%\right.$ at $20{ }^{\circ} \mathrm{C}$; Romanek et al., 1992) between the precipitating carbonate and the total dissolved inorganic carbon $\left(\mathrm{HCO}_{3}{ }^{-}\right)$. The $\delta^{13} \mathrm{C}$ value of Precambrian carbonates from the Lesser Himalaya is $0.7 \pm 1.2 \%$ (Singh et al., 1998). The $\mathrm{Sr}-\mathrm{Nd}$ isotopic variability (Fig. 10a, b) suggests increasing sediment contribution from the LH during MIS4 as a result of the higher extent of glacial cover over the $\mathrm{HH}$ during this period. Therefore, higher contribution of inorganic carbon from the dissolution of Precambrian carbonate rocks in the LH during MIS4 may have resulted in a higher $\delta^{13} \mathrm{C}$ of precipitating carbonates during this period, relative to the MIS3 interglacial. Whereas lower $\delta^{13} \mathrm{C}$ of carbonates during MIS3 may be due to higher contribution from silicate weathering (from the $\mathrm{HH}$ ) derived $\mathrm{HCO}_{3}{ }^{-}$pool characterized by more depleted $\delta^{13} \mathrm{C}$ (Rahaman et al., 2011). This is consistent with our earlier conclusion that extensive glacial cover over the HH during glacial periods resulted in an increasing contribution of LH sediments. Thus it may be concluded that the variation in $\delta^{13} \mathrm{C}$ of carbonates is controlled by the extent of silicate (HH) versus carbonate $(\mathrm{LH})$ weathering at the Himalayan sources due to significant climatic shifts in the hinterland source area. This interpretation is in agreement with the conclusions derived from the variability in $\delta^{13}$ Cof pedogenic carbonates from the Ganga Plains by Rahaman et al. (2011).

\subsection{Inferences on paleovegetation from stable isotope proxies}

The $\delta^{13} \mathrm{C}$ values of soil carbonates have also been used as a proxy for vegetation, i.e., estimating the proportion of $\mathrm{C}_{3}$ vs. $\mathrm{C}_{4}$ plants prevailing at the time of carbonate formation (Cerling et al., 1989). The underlying assumption is that soil carbonate and organic matter are cogenetic and the only source of soil- $\mathrm{CO}_{2}$ is from in situ oxidation of soil organic carbon. Accordingly, $\delta^{13} \mathrm{C}$ of pedogenic carbonates should be $\sim 14-16 \%$ heavier than in situ soil organic matter (Cerling et al., 1989) considering a $4.4 \%$ diffusive enrichment in the biologically-derived $\mathrm{CO}_{2}$ and an additional $\sim 10.4 \%$ enrichment due to ${ }^{13} \mathrm{C}$ fractionation between gaseous $-\mathrm{CO}_{2}$ and calcite. Several studies have 
utilized $\delta^{13} \mathrm{C}$ of soil carbonates from the southern Ganga plains (Sinha et al., 2006b; Rahaman et al., 2011), eastern Ganga plains (Srivastava, 2001) and Bengal Basin (Alam et al., 1997) as a proxy for vegetation during the Quaternary. For example, Sinha et al. (2006b) used $\delta^{13} \mathrm{C}$ of calcretes in a sequence spanning the last $60 \mathrm{ka}$ from the southern interfluves of Ganga and estimated $\mathrm{C}_{4}$ plant proportion in the range $62-71 \%$, indicating a $\mathrm{C}_{4}$ dominant system. As argued earlier, carbonates in the present study area formed out of equilibrium with the soil $\mathrm{CO}_{2}$, a conclusion supported by lack of pedogenic features in the nodules. Nevertheless, $\delta^{13} \mathrm{C}$ of sediment organic carbon represents contribution of carbon from both $\mathrm{C}_{3}$ and $\mathrm{C}_{4}$ plant types in the area (average $\delta^{13} \mathrm{C}$ of $\mathrm{C}_{3}$ and $\mathrm{C}_{4}$ of $-26 \%$ and $-12 \%$ respectively; O'Leary, 1988), and therefore can be used as a direct proxy for estimating the relative proportion of $\mathrm{C}_{3}$ and $\mathrm{C}_{4}$ plants.

Several studies have reported the effect of temperature, atmospheric $\mathrm{CO}_{2}$ concentration $\left(\mathrm{pCO}_{2}\right.$ ), and humidity on the $\delta^{13} \mathrm{C}$ of $\mathrm{C}_{3}$ vs. $\mathrm{C}_{4}$ plants (see Tipple and Pagani, 2007 and references therein). Whereas $\mathrm{C}_{3}$ plants thrive under high $\mathrm{pCO}_{2}$ conditions, low $\mathrm{pCO}_{2}$ (and low stromatal conductance) favors more $\mathrm{C}_{4}$ plants (Farquhar et al., 1989; Cerling et al., 1997). Using $\delta^{13} \mathrm{C}$ of bulk organic matter from Bengal Fan sediments, Galy et al. (2008a) argued that both $\mathrm{pCO}_{2}$ and humidity were responsible for variability in the $\mathrm{C}_{3}: \mathrm{C}_{4}$ ratio during the last $19 \mathrm{ka}$. However, $\mathrm{pCO}_{2}$ is directly related to temperature with studies suggesting $\sim 30 \%$ decrease in $\mathrm{pCO}_{2}$ during the Quaternary glacial periods (Achyuthan et al., 2007). Andrews et al. (1998) correlated higher $\delta^{13} \mathrm{C}$ values (higher $\mathrm{C}_{4}$ contribution) in pedogenic nodules from Shergrah Trijunction in Rajasthan with low $\mathrm{pCO}_{2}$ and cold/arid conditions during the MIS4 and MIS2 glacial periods, and lower $\delta^{13} \mathrm{C}$ values (higher $\mathrm{C}_{3}$ contribution) with high $\mathrm{pCO}_{2}$ and warm/humid interglacial periods (25-60 ka) marked by strong monsoon conditions. However, Andrews et al. (1998) noted an alternate scenario that increasing evaporation of soil water during spring dry season due to increased heating of landmass may have resulted in the intensification of monsoon, favoring more $\mathrm{C}_{4}$ plants as a response to warmer and wetter conditions. In contrast, from the same study area in the Thar Desert, Achyuthan et al. (2007) reported low $\delta^{13} \mathrm{C}$ values in pedogenic carbonates from glacial and high $\delta^{13} \mathrm{C}$ from interglacial periods, suggesting increasing abundance of $\mathrm{C}_{3}$ plants during low $\mathrm{pCO}_{2}$ and glacial periods. Achyuthan et al. (2007) concluded that $\mathrm{pCO}_{2}$ alone may not explain the observed $\delta^{13} \mathrm{C}$ variability in their data. This 
idea is supported by studies (e.g., Pagani et al., 2005) that show Miocene $\mathrm{pCO}_{2}$ reconstruction is in disagreement with the well-known hypothesis that expansion of $\mathrm{C}_{4}$ plants around $7 \mathrm{Ma}$ was related to a distinct decrease in $\mathrm{pCO}_{2}$ (Cerling et al., 1997). Further, based on the isotopic study on pre-LGM to recent sediments from the western part of the Ganges-Brahmaputra delta, Sarkar et al. (2009) concluded that $\mathrm{C}_{3}$ to $\mathrm{C}_{4}$ transition depends on the combined effect of depositional environment, ecological niches (namely fire in an arid climate) and climate rather than $\mathrm{pCO}_{2}$ alone. Note that both Andrews et al. (1998) and Achyuthan et al. (2007) interpreted $\delta^{13} \mathrm{C}$ variability in pedogenic carbonates based on the assumption that soil carbonate precipitated strictly in equilibrium with soil $\mathrm{CO}_{2}$. Interestingly, if we assume isotopic equilibrium between GS carbonates and soil $\mathrm{CO}_{2}$, then $\delta^{13} \mathrm{C}$ variability of carbonates in this study (Fig. 10d) can be interpreted similar to that of Andrews et al. (1998), i.e., higher $\delta^{13} \mathrm{C}$ values in the GS carbonates during glacial MIS4 (cold/arid, low $\mathrm{pCO}_{2}$ ) indicates higher proportion of $\mathrm{C}_{4}$ plants compared with lower $\delta^{13} \mathrm{C}$ values during MIS3 interglacial (warm/wet, high $\mathrm{pCO}_{2}$ ) suggesting higher proportion of $\mathrm{C}_{3}$ plants. However, this would be in direct conflict with the isotopic composition of organic matter (Fig. 10e), and therefore $\delta^{13} \mathrm{C}_{\mathrm{SOM}}$ is used in this study as a proxy for paleovegetation.

The $\mathrm{C}_{3}$ plants have distinct advantage over $\mathrm{C}_{4}$ plants in mountain regions (Sage et al., 1999). Studies suggest that the Himalayan catchment has always been dominated by $\mathrm{C}_{3}$ plants (Blasco et al., 1996; Galy et al., 2008a). This is also reflected in the $\delta^{13} \mathrm{C}_{\text {SOM }}$ values ( -27.4 to $-23.2 \%$, Table 3 ) of GS cores, suggesting dominantly $\mathrm{C}_{3}$ plants in the Himalayan catchment during the last $\sim 75 \mathrm{ka}$. Two distinct negative excursions (up to $3 \%$ ) are observed in the $\delta^{13} \mathrm{C}_{\mathrm{SOM}}$ variability in the GS cores (Fig. 10e), both occurring during the cold/arid glacial stages. The $\delta^{13} \mathrm{C}_{\mathrm{SOM}}$ attains maximum negative value of $-27.4 \%$ (mostly $\mathrm{C}_{3}$ ) during MIS4 followed by an increase of $\sim 3.1 \%$ at the MIS3/4 transition, and further increase (albeit minor fluctuations) to a value of $\sim-24.1 \%$ around $\sim 20 \mathrm{ka}$. Subsequently, $\delta^{13} \mathrm{C}_{\text {SOM }}$ decreases suddenly by $\sim 3 \%$ from $\sim 20$ to $\sim 16$ ka to attain the maximum $\delta^{13} \mathrm{C}_{\mathrm{SOM}}$ of $-23.2 \%$ o (late MIS2/LGM), followed by a $2 \%$ increase by $10 \mathrm{ka}$. During MIS1, $\delta^{13} \mathrm{C}_{\mathrm{SOM}}$ also shows a decrease of $2 \%$ from $\sim 10 \mathrm{ka}$ to $\sim 8 \mathrm{ka}$, suggesting shift towards relatively colder/arid climate and less intense summer monsoon. Sinha et al. (2006a) studied multiple phases of clastic and evaporate deposits from the Sambhar playa in Rajasthan, India and identified a dry event (weak summer monsoon) around 7.5 
ka, although this time period generally coincides with Holocene Hypsithermal marked by warm climate. Further, Sirocko et al. (1993) reported predominant dolomitic-aeolian dust in the Arabian Sea core at $\sim 8.2 \mathrm{ka}$ and related it to a drier event. $\delta^{13} \mathrm{C}_{\text {SOM }}$ variability in the GS core clearly shows a general pattern: $\mathrm{C}_{3}$ plants were dominant during cold periods and less intense monsoonal climate, with minor increase (5-10\%) in $\mathrm{C}_{4}$ contribution during warm periods and more intense monsoon. However, this conclusion is not in agreement with the generally accepted notion from other studies from the Gangetic Plains or in the Bengal Fan sediments (e.g., Bera et al., 2010; Agrawal et al., 2012; Galy et al., 2008a) that propose intense summer monsoon (wetter conditions) during interglacial periods favors more $\mathrm{C}_{3}$ plants, whereas less intense monsoon (glacial period) favors more $\mathrm{C}_{4}$ plants.

In contrast to the generally accepted notion, several studies have attributed higher abundances of $\mathrm{C}_{4}$ plants to the intensity of summer rainfall. Both Paruelo and Lauenroth (1996) and Epstein et al. (1997) have shown that relative abundance of $C_{4}$ grasses in the Great Plains of USA increases with increase in mean annual temperature (MAT) and intensity of summer rainfall, with more summer rainfall and less winter precipitation favouring more $\mathrm{C}_{4}$ plants annually. Similar conclusions were also reached by Hattersley (1983) relating higher abundances in $\mathrm{C}_{4}$ plants across Australia with increasing summer rainfall (and warmer conditions), but not the mean annual rainfall. Fischer et al. (2008) analyzed $\delta^{13} \mathrm{C}$ of soil organic matter and fine roots from 55 native grassland sites across the US and Canadian Great Plains, and showed a strong control of $\% \mathrm{C}_{4}$ plants by the mid-summer climate. Sanyal et al. (2010) attempted to understand variation in SW Indian summer monsoon over the last $11 \mathrm{Ma}$ using $\delta \mathrm{D}$ in pedogenic clays and $\delta^{18} \mathrm{O}$ in carbonate nodules from chronologically well-constrained sections of Siwalik Himalaya. They stated that "expansion of $\mathrm{C}_{4}$ plants during the late MiocenePliocene time could be entirely due to monsoon intensification that favored $\mathrm{C}_{4}$ respiration in a warm and seasonally variable rainfall regime" (p.1). These studies strongly suggest that MAT along with the intensity of summer rainfall controls a shift in $\mathrm{C}_{3}$ to $\mathrm{C}_{4}$ dominated ecosystems, i.e., warmer and wetter summer conditions favor more $\mathrm{C}_{4}$ plants. On the basis of $\delta^{13} \mathrm{C}$ values in pedogenic carbonates from the Thar Desert, Achyuthan et al. (2007) suggested that expansion of $\mathrm{C}_{4}$ plants coincided with periods of intense summer rainfall as a result of stronger SW monsoon during interglacial periods, whereas higher $\mathrm{C}_{3}$ plants coincided with more winter rain (weak $\mathrm{SW}$ monsoon during glacial periods). 
Following this argument, more negative $\delta^{13} \mathrm{C}_{\mathrm{SOM}}$ values in our data during cold glacial periods relative to more positive values during interglacial periods can be explained by both less intense summer rainfall and low MAT value during glacial periods favoring more $\mathrm{C}_{3}$ plants. On the other hand, relatively more summer rainfall and higher MAT value during the interglacial periods favored slightly higher $\mathrm{C}_{4}$ plant abundances. Also, $\delta^{13} \mathrm{C}_{\mathrm{SOM}}$ increases sharply at the interface of MIS2 and MIS1 (Fig. 10e) suggesting increasing $\mathrm{C}_{4}$ proportions, consistent with climate reconstructions indicating increasing moisture content in the Himalaya from the LGM to mid-Holocene period (Herzschuh, 2006).

\section{Conclusions}

This study presents first detailed record of geochemistry of buried channel sand down to 40$45 \mathrm{~m}$ depths beneath the Ghaggar Plains in NW India. Sediment geochemistry is used to establish temporal variations in sediment provenance vis-à-vis climate variability. The ${ }^{87} \mathrm{Sr} /{ }^{86} \mathrm{Sr}$ and ${ }^{144} \mathrm{Nd} /{ }^{143} \mathrm{Nd}$ ratios in bulk silicate fractions of the core sediments plot between the Higher and Lesser Himalayan endmember sources. Isotopic ratios clearly indicate that the sediments representing buried channel sand bodies were deposited in the Ghaggar Plains through a large river system possibly originating in the Higher Himalaya. This is consistent with the hypothesis provided by others, mainly based on remote-sensing data, that these buried channel sands were deposited by a large river system (e.g., paleo-Sutlej) sourced in the hinterland Himalayas. Temporal variations in $\mathrm{Sr}-\mathrm{Nd}$ isotope ratios in the sediments suggest shifts in the major sediment regime between the Higher Himalayan $\left({ }^{\circ}{ }^{87} \mathrm{Sr} /{ }^{86} \mathrm{Sr}\right.$ and high ${ }^{144} \mathrm{Nd} /{ }^{143} \mathrm{Nd}$ ) and Lesser Himalayan (high ${ }^{87} \mathrm{Sr} /{ }^{86} \mathrm{Sr}$ and low ${ }^{144} \mathrm{Nd} /{ }^{143} \mathrm{Nd}$ ) sources corresponding to changes in glacial cover as result of major climatic shifts. Essentially, extensive glacial cover over the Higher Himalaya during glacial periods resulted in an increase in the contribution of Lesser Himalayan sediments, thus clearly reflecting climate-controlled sediment erosion in the catchment areas of hinterland Himalaya.

Decrease in $\delta^{18} \mathrm{O}$ values of carbonate nodules during glacial periods is related to the low $\delta^{18} \mathrm{O}$ value of precipitation due to combined effect of temperature dependent oxygen isotope fractionation between water vapor and condensate and fraction of vapor remaining in the air mass. Temporal 
variation in $\delta^{13} \mathrm{C}$ values of carbonate nodules may be explained by shift in contribution of DIC from the weathering of silicate (Higher Himalaya) to carbonate (Lesser Himalaya) rocks in response to climatic change from interglacial to glacial period and vice versa. Finally, $\delta^{13} \mathrm{C}$ values of SOM suggest dominantly $\mathrm{C}_{3}$ plants in the Himalayan catchment during the last $75 \mathrm{ka}$. Variability in $\delta^{13} \mathrm{C}_{\mathrm{SOM}}$ also suggests $\mathrm{C}_{3}$ plants were dominant during cold and less intense monsoonal climate, with minor increase (5-10\%) in $\mathrm{C}_{4}$ contribution during warm and more intense monsoon, which is in contrast to the generally accepted notion that intense summer monsoon (wetter conditions) during interglacial periods favors more $\mathrm{C}_{3}$ plants.

\section{Acknowledgments}

This paper is a part of the Ph.D. thesis of AS at IIT Kanpur. We thank Dr Sunil K. Singh of PRL Ahmedabad, and Dr David Hodell of Cambridge University for help in isotope analyses. Thanks are also due to Mohd. Amir for doing the stable isotopic analyses at IIT Kanpur. We also thank Drs. Sampat K. Tandon and Christian France-Lannord for insightful discussions. Finally, we thank two anonymous reviewers and Prof. Thomas Algeo (Editor) for a thoughtful and thorough review. 


\section{References}

Achyuthan H., Quade J., and Loe L., 2007. Stable isotopic composition of pedogenic carbonates from the eastern margin of the Thar Desert, Rajasthan, India. Quat. Int. 162-163, 50-60.

Agrawal, S., Sanyal, P., Sarkar, A., Jaiswal, M. K., and Dutta, K., 2012. Variability of Indian monsoonal rainfall over the past $100 \mathrm{ka}$ and its implication for $\mathrm{C}_{3}-\mathrm{C}_{4}$ vegetational change. Quat. Res. 77 (1), 159-170.

Alam, M.S., Keppens, E., and Paepe, R., 1997. The use of oxygen and carbon isotope composition of pedogenic carbonates from Pleistocene palaeosols in NW Bangladesh, as palaeoclimatic indicators. Quat. Sci. Rev. 16, 161-168.

Alizai, A., Carter, A., Clift, P.D., VanLaningham, S., Williams, J. C., and Kumar, R. 2011. Sediment provenance, reworking and transport processes in the Indus River by $\mathrm{U}-\mathrm{Pb}$ dating of detrital zircon grains. Global and Planet. Change 76 (1-2), 33-55.

Alonso-Zarza, A.M., 2003. Palaeoenvironmental significance of palustrine carbonates and calcretes in the geological record. Earth-Sci. Rev. 60, 261-298.

Andrews, J.E., Singhvi, A.K., Kailath, A.J., Kuhn, R., Dennis, P.F., Tandon, S.K., and Dhir, R.P., 1998. Do Stable Isotope Data from Calcrete Record Late Pleistocene Monsoonal Climate Variation in the Thar Desert of India? Quat. Res. 50 (3), 240-251.

Bera, M.K., Sarkar, A., Tandon, S.K., Samanta, A., and Sanyal, P., 2010. Does burial diagenesis reset pristine isotopic compositions in paleosol carbonates? Earth Planet. Sci. Lett. 300 (1-2), 85-100.

Blasco, F., Bellan, M.F., and Aizpuru M., 1996. A vegetation map of tropical continental Asia at scale 1.5 million. J. Veg. Sci. 7, 623-634.

Bookhagen, B., Thiede, R.C., and Strecker, M.R., 2005. Late Quaternary intensified monsoon phases control landscape evolution in the northwest Himalaya. Geology 33 (2), 149-152.

Bouvier, A., Vervoort, J. D., and Patchett, P. J., 2008. The Lu-Hf and Sm-Nd isotopic composition of CHUR: Constraints from unequilibrated chondrites and implications for the bulk composition of terrestrial planets. Earth Planet. Sci. Lett. 273 (1-2), 48-57.

Bryson, R.A., and Swain, A.M., 1981. Holocene variations of monsoon rainfall in Rajasthan. Quat. Res. 16 (2), 135-145.

Burbank, D.W., Blythe, A.E., Putkonen, J., Pratt-Sitaula, B., Gabet, E., Oskin, M., Barros, A., and Ojha, T.P., 2003. Decoupling of erosion and precipitation in the Himalayas. Nature 426, 652-655, doi:10.1038/nature02187.

Cerling, T., Quade, J., Wang, Y. and Bowman, J.R., 1989. Carbon isotopes in soils and paleosoils as ecology and paleoecology indicators. Nature 341, 138-39.

Cerling, T.E., Wang, Y., and Quade, J., 1993. Expansion of C4 ecosystems as an indicator of global ecological change in the late Miocene. Nature 361, 344-345.

Cerling, T.E., Harris, J.M., MacFadden, B.J., Leakey, M.G., Quade, J., Eisenmann, V., and Ehleringer, J.R., 1997. Global vegetation change through the Miocene/Pliocene boundary. Nature 389, 153 158.

Clemens, S., Prell, W., Murray, D., Shimmield, G., and Weedon, G., 1991. Forcing mechanisms of the Indian Ocean monsoon. Nature 353 (6346), 720-725.

Clift, P.D., Giosan, L., Carter, A., Garzanti, E., Galy, V., Tabrez, A.R., and Rabbani, M.M., 2010. Monsoon control over erosion patterns in the Western Himalaya: possible feed-back into the 
tectonic evolution. Geo. Soc., London, Spe. Pub. 342 (1), 185-218.

Coplen T.B., Kendall C., and Hopple J., 1983. Comparison of stable isotope reference material. Nature 302, 236-238.

Dansgaard, W., 1964. Stable isotopes in precipitation. Tellus 16, 436-468.

Derry, L.A. and France-Lanord, C., 1996. Neogene Himalayan weathering history and river ${ }^{87} \mathrm{Sr} /{ }^{86} \mathrm{Sr}$ : impact on the marine Sr record. Earth Planet. Sci. Lett. 142, 59-74.

Dhir, R.P., Tandon, S.K., Sareen, B.K., Ramesh, R., Rao, T.K.G., Kailath, A.J., and Sharma, N., 2004. Calcretes in the Thar Desert: Genesis, chronology and palaeoenvironment. J. Earth Syst. Sci. 113 (3), 473-515.

Driese, S.G. and Mora, C.I., 1993. Physico-chemical environment of pedogenic carbonate formation in Devonian vertic paleosols, central Appalachians, U.S.A. Sedimentology 40, 199- 216.

Duplessy, J.C., 1982. Glacial to interglacial contrasts in the northern Indian Ocean. Nature 295, 494498.

Enzel, Y., Ely, L., Mishra, S., Ramesh, R., Amit, R., Lazar, B., Rajguru, S.N., Baker, V.R., Sandler, A., 1999. High-resolution Holocene environmental changes in the Thar Desert, north western India. Science 284, 124-128.

Epstein, H.E., Lauenroth, W.K., Burke, I.C., and Coffin, D.P., 1997. Productivity patterns of C3 and C4 functional types in the U.S. Great Plains. Ecology 78, 722-731.

Farquhar, G.D., Ehleringer, J.R., and Hubick, K.T., 1989. Carbon Isotope discrimination and photosynthesis. Annu. Rev. Plant Physiol. Plant Mol. Biol. 40, 503-537.

Fischer, J.C., Tieszen, L.L., Schimel, D.S., 2008. Climate controls on C3 vs. C4 productivity in North American grasslands from carbon isotope composition of soil organic matter. Global Change Biology 14, 1-15.

Fontugne, M.R., and Duplessy, J.C., 1986. Variations of the monsoon regime during the upper quaternary: evidence from carbon isotopic record of organic matter in North Indian sediment cores. Palaeogeogr. Palaeoclimatol. Palaeoecol. 56, 69-88.

Galy, A., and France-Lanord, C., 2001. Higher erosion rates in the Himalaya: Geochemical constraints on riverine fluxes. Geology 29, 23-26.

Galy, V., France-Lanord, C., Faure, P., Kudrass, H., Palhol, F., and Singh, S. K., 2008a. C 4 plants decline in the Himalayan basin since the Last Glacial Maximum. Quat. Sci. Rev. 27 (1314), 1396-1409.

Galy, V., France-Lanord, C., and Lartiges, B., 2008b. Loading and fate of particulate organic carbon from the Himalaya to the Ganga Brahmaputra delta. Geochim. Cosmochim. Acta 72 (7), $1767-1787$.

Galy, V., France-Lanord, C., Peucker-Ehrenbrink, B., and Huyghe, P., 2010. Sr-Nd-Os evidence for a stable erosion regime in the Himalaya during the past 12Myr. Earth Planet. Sci. Lett. 290 (34), 474-480.

Garçon, M., Chauvel, C., France-Lanord, C., Huyghe, P., and Lavé, J., 2013. Continental sedimentary processes decouple Nd and Hf isotopes. Geochim. Cosmochim. Acta 121, 177-195.

Garçon, M., Chauvel, C., France-Lanord, C., Limonta, M., and Garzanti, E., 2014. Which minerals control the $\mathrm{Nd}-\mathrm{Hf}-\mathrm{Sr}-\mathrm{Pb}$ isotopic compositions of river sediments? Chem. Geol. 364, 42-55.

Garçon, M., and Chauvel, C., 2014. Where is basalt in river sediments, and why does it matter? 
EarthPlanet. Sci. Lett. 407, 61-69.

Garzanti, E., Andò, S., France-Lanord, C., Vezzoli, G., Censi, P., Galy, V., and Najman, Y., 2010. Mineralogical and chemical variability of fluvial sediments 1. Bedload sand (Ganga-Brahmaputra, Bangladesh). Earth Planet. Sci. Lett. 299, 368-381.

Goswami, V., Singh, S.K., Bhushan, R., and Rai, V.K., 2012. Temporal variations in ${ }^{87} \mathrm{Sr} /{ }^{86} \mathrm{Sr}$ and $\varepsilon_{\mathrm{Nd}}$ in sedimentsof the southeastern Arabian Sea: Impact of monsoon and surface water circulation. Geochem. Geophy. Geosys. 13 (1), 1-13.

Grootes, P.M., 1993. Interpreting continental oxygen isotope records. In: Swart, P.K., Lohmann, K.L., McKenzie, J., Savin, S. (Eds.), Climate Change in Continental Isotopic Records. Amer. Geophy. Union, Washington, DC 37-46.

Hattersley, P.W., 1983. The distribution of C3 and C4 grasses in Australia in relation to climate. Oecologia 57, 113-128.

Herzschuh, U., 2006. Palaeo-moisture evolution in monsoonal Central Asia during the last 50,000 years. Quat. Sci. Rev. 25 (1-2), 163-178.

Jain, M., and Tandon, S. K., 2003. Fluvial response to Late Quaternary climate changes, western India. Quat. Sci. Rev. 22 (20), 2223-2235.

Jain, M., Tandon, S.K., Singhvi, A.K., Mishra, S., and Bhatt, S.C., 2005. Quaternary alluvial stratigraphic development in a desert setting: a case study from Luni river basin, Western India. In Fluvial Sedimentology VII, Eds. M. Blum and S. Marriott, International Association of Sedimentologists, Special Publication 35, 349-371.

Kim, S.T., and O'Neil, J.R., 1997. Equilibrium and nonequilibrium oxygen isotope effects in synthetic carbonates. Geochim. Cosmochimic. Acta 61, 3461-3475.

Kumar, B., Rai, S. P., Saravana Kumar, U., Verma, S. K., Garg, P., Vijaya Kumar, S.V., Jaiswal, R., Purendra, B.K., Kumar, S.R., and Pande, N.G., 2010. Isotopic characteristics of Indian precipitation. Water Resour. Res. 46, W12548.

Li, C., and Yang, S.Y., 2010. Is chemical index of alteration a reliable proxy for chemical weathering in global drainage basins? Am. J. Sci. 310, 111-127.

Lupker, M., France-Lanord, C., Lavé, J., Bouchez, J., Galy, V., Métivier, F., Gaillardet, J., Lartiges, B., and Mugnier, J.-L., 2011. A Rouse-based method to integrate the chemical composition of river sediments: application to the Ganga basin. J. Geophys. Res. 116, F04012, http://dx.doi.org/10.1029/2010jf001947.

Lupker, M., Lanord, C.F., Galy, V., Lavé, J., Gaillardet, J., Gajurel, A.P., Guilmette, C., Rahmane, M., Singh, S.K., and Sinha, R., 2012. Predominant floodplain over mountain weathering of Himalayan sediments (Ganga basin). Geochim. Cosmochimic. Acta 84, 410-432.

Lupker, M., Lanord, C.F., Galy, V., and Lavé, J., 2013. Incresing chemical weathering in the Himalayan sytem since the Last Galcial Maximum. Earth Planet. Sci. Lett. 365, 243-252.

Myrow, P.M., Hughes, N.C., Derry, L.A., McKenzie, N.R., Jiang, G., Webb, A.A.G., Banerjee, D.M., Paulsen, T.S., and Singh, B.S., 2015. Neogene marine isotopic evolution and the erosion of Lesser Himalayan strata: Implications for Cenozoic tectonic history. Earth Planet. Sci. Lett. 417, 142-150.

Najman, Y., 2006. The detrital record of orogenesis: A review of approaches and techniques used in the Himalayan sedimentary basins. Earth-Sci. Rev. 74 (1-2), 1-72.

Nesbitt, H.W., and Young, G.M., 1982. Early Proterozoic climates and plate motions inferred from major element chemistry of lutites. Nature $299,715-717$. 
Oldham, C.F., 1893. The Sarasvati and the lost river of the Indian desert. Journal, Royal Asiatic Society 34, 49-76. As Republished in Memoirs, Geol. Soc. India 42, 89-93 (1999).

O’Leary, M.H., 1988. Carbon isotopes in photosynthesis. Bioscience 38, 325-336.

Overpeck, J., Anderson, D., Trumbore, S., and Prell, W., 1996. The southwest Indian Monsoon over the last 18000 years. Climate Dynamics 12, 213-225.

Owen., L.A., Finkel., R.C., and Caffee., M.W., 2002. A note on the extent of glaciation throughout the Himalaya during the global Last Glacial Maximum. Quat. Sci. Rev. 21 (1), 147-157.

Pagani, M., Zachos, J.C., Freeman, K.H., Tipple, B., and Bohaty, S., 2005. Marked decline in atmospheric carbon dioxide concentrations during the Paleogene. Science 309, 600-603.

Paruelo, J.M., and Lauenroth, W.K., 1996. Relative Abundance of Plant Functional Types in Grasslands and Shrublands of North America. Ecological Applications 6, 1212-1224.

Prell, W.L., and Kutzbach, J.E., 1987. Monsoon variability over the past 150,000 years. J. Geophys. Res. 92 (D7), 8411-8425.

Quade, J., Cerling, T.E., and Bowman, J.R., 1989. Development of the Asian Monsoon revealed by marked ecological shift in the latest Miocene in northern Pakistan. Nature 342,163-166.

Rahaman, W., Singh, S.K., Sinha, R., and Tandon, S.K., 2009. Climate control on erosion distribution over the Himalaya during the past $100 \mathrm{ka}$. Geology 37 (6), 559-562.

Rahaman, W., Singh, S.K., Sinha, R., and Tandon, S.K., 2011. Sr, C and O isotopes in carbonate nodules from the Ganga Plain: Evidence for recent abrupt rise in dissolved ${ }^{87} \mathrm{Sr} /{ }^{86} \mathrm{Sr}$ ratios of the Ganga. Chem. Geol. 285 (1-4), 184-193.

Richards, A., Argles, T., Harris, N., Parrish, R.R., Ahmad, T., Darbyshire, F., and Draganits, E., 2005. Himalayan architecture constrained by isotopic markers from clastic sediments. Earth Planet. Sci. Lett. 236, 773-796.

Romanek, C.S., Grossman, E.L., and Morse, J.W., 1992. Carbon isotopic fractionation in synthetic aragonite and calcite: Effects of temperature and precipitation rate. Geochim. Cosmochim. Acta 56 (1), 419-430.

Rostek, F., Ruhland, G., Bassinot, F., Miller, P.J., Labeyrie, L.D., and Bard, E., 1993. Fluctuations of the Indian Monsoon regime during the last 170,000 years: evidence from sea surface temperature, salinity and organic carbon records. NATO Workshop Global precipitations and climate change, L'Agelonde (FR), 27 September-1 October Abstracts, 17.

Rozanski K., Araguas-Araguas L., and Gonfiantini R., 1993. Isotopic patterns in modern global precipitation. Climate Change in Continental Isotopic Records. Am. Geophys. Union, Geophys. Monogr. 78, 1-36.

Rudnick, R.L., and Gao, S., 2003. Composition of the Continental Crust. In D. H. Editors-in-Chief: Heinrich and K. T. Karl (Eds.), Treatise on Geochemistry, Oxford: Pergamon, $1-64$.

Sage, R.F., Wedin, D.A., and Li, M., 1999. The biogeography of $\mathrm{C}_{4}$ photosynthesis: patterns and controlling factors. In: Sage, R.F., Monson, R.K. (Eds.), C 4 Plant Biology, 313-373.

Sanyal, P., Sarkar, A., Bhattacharya, S.K., Kumar, R., Ghosh, S.K., and Agrawal, S., 2010. Intensification of monsoon, microclimate and asynchronous $\mathrm{C}_{4}$ appearance: Isotopic evidence from the Indian Siwalik sediments. Palaeogeogr. Palaeoclimatol. Palaeoecol. 296 (12), 165-173.

Sarkar, A., Sengupta, S., McArthur, J.M., Ravenscroft, P., Bera, M.K., Bhushan, R., Samanta, A., and Agrawal, S., 2009. Evolution of Ganges-Brahmaputra western delta plain: clues from 
sedimentology and carbon isotope. Quat. Sci. Rev. 28, 2564-2581.

Sengupta, S., and Sarkar, A., 2006. Stable isotope evidence of dual (Arabian Sea and Bay of Bengal) vapor sources in monsoonal precipitation over north India. Earth Planet. Sci. Lett. 250, 511-521.

Shakleton, N.J., and Opdyke, N.D., 1973. Oxygen isotope an palaeomagnetic stratigraphy of equatorial Pacific Core V28-238: Oxygen isotope temperature and ice volumes on a $10^{5}$ year scale. Quat. Res. 3, 39-55.

Sharp, Z., 2007. Principles of Stable Isotope Geochemistry. Pearson Prentice Hall, Upper Saddle River, NJ, pp. 344.

Sheldon, N.D., and Tabor, N.J., 2009. Quantitative paleoenvironmental and paleoclimatic reconstruction using paleosols. Earth-Sci. Rev. 95, 1-52.

Sheldon, N.D., Retallack, G.J., and Tanaka, S., 2002. Geochemical climofunctions from North American Soils and Application to paleosols across the Eocene-Oligocene boundary in Oregon. J. Geol. 110, 687-696.

Singh, G., Joshi, R.D., Chopra, S.K., and Singh, A.B., 1974. Late Quaternary History of Vegetation and Climate of the Rajasthan desert, India. Phil. Trans. R. Soc. B 267, 467-501.

Singh, G., Wasson, R.J., and Agrawal, D.P., 1990. Vegetational and seasonal climatic changes since the last full glacial in the Thar Desert, northwestern India. Review of Palaeobotany and Palynology. The Proceedings of the 7th International Palynological Congress (Part I) 64 (14), 351-358.

Singh, P., 2009. Major, trace and REE geochemistry of the Ganga River sediments: Influence of provenance and sedimentary processes. Chem. Geol. 266 (3-4), 242-255.

Singh, S.K., and France-Lanord, C., 2002. Tracing the distribution of erosion in the Brahmaputra watershed from isotopic compositions of stream sediments. Earth Planet. Sci. Lett. 202 (34), 645-662.

Singh, S.K., Rai, S.K., and Krishnaswami, S., 2008. Sr and Nd isotopes in river sediments from the Ganga Basin: Sediment provenance and spatial variability in physical erosion. J. Geophys. Res. 113, F03006, http://dx.doi.org/10.1029/2007jf000909.

Singh, S.K., Trivedi, J.R., Pande, K., Ramesh, R., and Krishnaswami, S., 1998. Chemical and strontium, oxygen, and carbon isotopic compositions of carbonates from the Lesser Himalaya: implications to the strontium isotope composition of the sourcewaters of the Ganga, Ghaghara, and the Indus rivers. Geochim. Cosmochimic. Acta 62, 743-755.

Singhvi, A.K., Banerjee, D., Ramesh, R., Rajaguru, S.N., and Gogte, V., 1996. A luminescence method for dating 'dirty' pedogenic carbonates for paleoenvironmental reconstruction. Earth Planet. Sci. Lett. 139, 321-332.

Singhvi, A.K., Sharma, Y.P., and Agrawal, D.P., 1982. Thermo-luminescence dating of sand dunes in Rajasthan, India. Nature 295 (5847), 313-315.

Sinha, R., Yadav, G.S., Gupta, S., Singh, A., and Lahiri, S.K., 2013. Geo-electric resistivity evidence for subsurface palaeochannel systems adjacent to Harappan sites in northwest India. Quat. Int. 308$309,66-75$.

Sinha, R., Smykatz-Kloss, W., Stueben, D., Harrison, S.P., Berner Z., and Kramar, U., 2006a. Late Quaternary palaeoclimatic reconstruction from the lacustrine sediments of the Sambhar playa core, Thar Desert margin, India. Palaeogeogr. Palaeoclimatol. Palaeoecol. 233/3-4, 252-270.

Sinha, R., Tandon, S.K., Sanyal, P., Gibling, M.R., Stuben, D., Berner, Z., and Ghazanfari, P. 2006b. 
Calcretes from a Late Quaternary interfluve in the Ganga Plains, India: Carbonate types and isotopic systems in a monsoonal setting. Palaeogeogr. Palaeoclimatol. Palaeoecol. 242 (34), 214-239.

Sirocko, F.,Sarnthein, M., Erlenkeuser, H., Lange, H., Arnold, M., and Duplessy, J.C., 1993. Century-scale events in monsoonal climate over the past 24,000 years. Nature 364, $322-324$; doi: $10.1038 / 364322 \mathrm{a} 0$.

Srivastava, P., 2001. Paleoclimatic implications of pedogenic carbonates in Holocene soils of the Gangetic Plains. Palaeogeogr. Palaeoclimatol. Palaeoecol. 177, 207-222.

Stein, A., 1942. A Survey of Ancient Sites along the "Lost" Sarasvati River. The Geographical Journal 99 (4), 173-182.

Thompson, L.G., Yao, T., Davis, M.E., Henderson, K.A., Mosley-Thompson, E., Lin, P.-N., Beer, J., Synal, H.-A., Cole-Dai, J., and Bolzan, J.F., 1997. Tropical climate instability: the last Glacial cycle from a Qinghai-Tibetan ice core. Science 276, 1821-1825.

Tipple, B.J. and Pagani, M., 2007. The early origins of terrestrial C4 photosynthesis. Annu. Rev. Earth Planet. Sci. 35, 435-461.

Tripathi, J. K., Bock, B., Rajamani, V., and Eisenhauer, J., 2004. Is river Ghaggar, Saraswati? Geochemical constraints. Curr. Sci. 87, 1141-1145.

Valdiya, K.S., 1980, Geology of Kumaun Lesser Himalaya. Wadia Institute of Himalayan Geology, Dehradun, $291 \mathrm{pp}$.

Valdiya, K.S., 1996. Saraswati that disappeared. Resonance 1(5), 19-28.

Van Campo, E., 1986. Monsoon fluctuations in two 20,000-yr BP oxygen isotope/pollen records off southwest India. Quat. Res. 26, 376-388.

Van Campo, E., Duplessy, J.C., and Rossignol-Strick, M., 1982. Climatic conditions deduced from a 150-kyr oxygen isotope-pollen record from the Arabian Sea. Nature 296, 56-59.

Vannay, J.-C., Grasemann, B., Rahn, M., Frank, W., Carter, A., Baudraz, V., and Cosca, M., 2004. Miocene to Holocene exhumation of metamorphic crustal wedges in the NW Himalaya: Evidence for tectonic extrusion coupled to fluvial erosion. Tectonics 23 (1), 1-24.

Wasson, R.J., Smith, G.I., and Agrawal, D.P., 1984. Late quaternary sediments, minerals, and inferred geochemical history of Didwana Lake, Thar Desert, India. Palaeogeogr. Palaeoclimatol. Palaeoecol. 46 (4), 345-372.

Wasson, R.J., Rajaguru, S.N., Misra, V.N., Agarwal, D.P., Dhir, R.P., and Singhvi, A.K., 1983. Geomorphology, Late Quaternary stratigraphy and palaeoclimatology of the Thar dune field. Zeitschrift fur Geomorphologie, Neue Folge 45, 117-151.

Webb, A.A.G., Yin, A., Harrison, T.M., Célérier, J., Gehrels, G.E., Manning, C.E., and Grove, M. 2011. Cenozoic tectonic history of the Himachal Himalaya (northwestern India) and its constraints on the formation mechanism of the Himalayan orogen. Geosphere 7 (4), 1013-1061.

Wright, V.P., and Tucker, M.E., 1991. Introduction. In "Calcretes. International Association of Sedimentologists Reprint” (V. P. Wright and M. E. Tucker, Eds.) 2, 1-22.

Yashpal, S.B., Sood, R.K., and Agrawal, D.P., 1980. Remote sensing of the 'lost' Saraswati' river. Proceedings of the Indian Academy of Sciences (Earth and Planet Science) 89, 317-331.

Yin, A., 2006. Cenozoic tectonic evolution of the Himalayan orogen as constrained by along-strike variation of structural geometry, exhumation history, and foreland sedimentation. Earth-Sci. Rev. $76(1-2), 1-131$. 


\section{Figure Captions}

Fig. 1. (a) Modeled record of strength of SW Indian Monsoon from Prell and Kutzbach (1987). (b) Compilation of available records of SW Indian monsoon variability for the past $\sim 120$ ka derived from marine and continental proxies from NW India: $1-\delta^{18} \mathrm{O}$ of planktonic foraminifera in sediment core from Indian Ocean (Duplessy, 1982); $2-\delta^{13} \mathrm{C}$ of organic matter in sediment cores from Indian Ocean (Fontugne and Duplessy, 1986); $3-\delta^{18} \mathrm{O}$ of benthic and planktonic foraminifera, and pollen record in a sediment core from Arabian Sea (Van Campo et al., 1982); $4-\delta^{18} \mathrm{O}$ of planktonic foraminifera and pollen record in sediment cores from Arabian Sea (Van Campo, 1986); 5- Record of sea surface temperature, salinity, and organic carbon content in a deep sea sediment core from Arabian sea (Rostek et al., 1993); $6-\delta^{18} \mathrm{O}$ of planktonic foraminifera, \% G. bulloides and \% pollen data in sediment cores from Arabian Sea (Overpeck et al., 1996); $7-\delta^{13} \mathrm{C}$ of organic matter and carbonates, and $\% \mathrm{CaCO}_{3}$ in sediments from Lunkaransar lake, NW India (Enzel et al., 1999); 8- Pollen record in sediments from Didwana lake, NW India (Singh et al., 1990); 9- Mineral and geochemical record of Didwana lake sediment, NW India (Wasson et al., 1984); 10-Mineralogy of sediment and $\delta^{18} \mathrm{O}$ of carbonates in Sambhar lake, NW India (Sinha et al., 2006b); $11-\delta^{18} \mathrm{O}$ of calcrete from Thar desert, NW India (Andrew et al., 1998); 12- Dune activity in Thar desert, India (Wasson et al., 1983); 13$\delta^{18} \mathrm{O}$ and $\delta^{13} \mathrm{C}$ in soil carbonates and $\delta^{13} \mathrm{C}$ in soil organic matter in sediment cores from Ganga plains, India (Agrawal et al., 2012) are shown for comparison. In this study, the boundaries of glacial and interglacial stages (MIS-Marine Isotope Stage) are the same as defined by Shackleton and Opdyke (1973) in the Pacific core V28-238: MIS1 and MIS2 at $13 \mathrm{ka}$, MIS2 and MIS3 at $32 \mathrm{ka}$, MIS3 and MIS4 at $64 \mathrm{ka}$, MIS4 and MIS5 at $75 \mathrm{ka}$.

Fig. 2. (a) Simplified geological map of NW Himalaya along with major drainage and core location on GS transect. The map is based on the compilations taken from Web et al., 2011, Yin (2006), Vannay et al. (2004), and Myrow et al. (2015). (b)Lithologies of GS-10 and GS-11 drill cores showing depthwise sampling locations for bulk sediments (circles) and carbonate nodules (squares). Inset shows core locations along the GS-transect near the village of Kalibangan $\left(29^{\circ} 28^{\prime} 13.66^{\prime \prime} \mathrm{N}, 74^{\circ} 07^{\prime} 48.85^{\prime \prime} \mathrm{E}\right)$ on the left bank of modern Ghaggar. GS-10 is located approximately $1.5 \mathrm{~km} \mathrm{NW}$ of GS-11. In the Index, F, $\mathrm{C}$, and A represent floodplain facies, channel facies, and aeolian facies, respectively. Note that the ages shown in the lithologs represent OSL ages obtained on the samples from the corresponding layers. Details on OSL methodology, age determination, and interpretation will be presented elsewhere (Thomsen et al., manuscript in preparation). See supplementary text for brief methodology of OSL ages.

Fig. 3. Variations in major oxides (wt \%) against $\mathrm{Al}_{2} \mathrm{O}_{3}(\mathrm{wt} \%)$ content in the GS core sediments. Also shown for comparison are modern-river sediments (Alizai et al., 2011 and Singh, 2009) from the northwest Himalaya, and abundances in the Upper Continental Crust (UCC) (Rudnick and Gao, 2003) and Post Archean Australian Shales (PAAS) (Taylor and McLennan, 1985). Modern rivers: Indus (I), Sutlej (S), Ghaggar (Gh), Yamuna (Y), and Ganga (Gn).

Fig. 4. A-CN-K ternary plot (Nesbitt and Young, 1982) showing composition of GS-10 and GS-11 core sediments. Also shown for comparison are modern-river sediments from Himalaya (same as in Fig. 3), average values for world river sediments (Li and Yang, 2010), UCC, and PAAS.

Fig. 5. Variations in (a-b) ${ }^{87} \mathrm{Sr} /{ }^{86} \mathrm{Sr}$ and $\varepsilon_{\mathrm{Nd}} \mathrm{vs}$. $\mathrm{Al}_{2} \mathrm{O}_{3} / \mathrm{SiO}_{2}$, which is a proxy for grain size (Lupker et al., 2011); (c) ${ }^{87} \mathrm{Sr} /{ }^{86} \mathrm{Sr}$ vs. $\mathrm{Rb} / \mathrm{Sr}$; and (d) $\varepsilon_{\mathrm{Nd}}$ vs. Sm/Nd. Poor correlation and large scatter shown in the plots suggest minimum effect of mineral/grain-size sorting on the $\mathrm{Sr}$ and $\mathrm{Nd}$ isotopic ratios in the GS core sediments. Therefore temporal variations in ${ }^{87} \mathrm{Sr} /{ }^{86} \mathrm{Sr}$ and $\varepsilon_{\mathrm{Nd}}$ can be used to infer change in sediment supply from different Himalayan sources.

Fig. 6. $\varepsilon_{\mathrm{Nd}} \mathrm{vs} .{ }^{87} \mathrm{Sr} /{ }^{86} \mathrm{Sr}$ isotopic ratios in the bulk silicate fraction of GS core sediments. Also shown for comparison are modern sediments from Sutlej and Ghaggar rivers, and Thar Desert (Tripathi et al., 2004). The ranges of isotopic composition of Higher Himalayan (HH) and Lesser Himalayan (LH) lithologic units are represented by rectangles (Singh et al., 2008); fields shown by ellipses for LH and HH sources are from Galy et al. (2010); modern sediment from Ganga basin (Singh, 2008) are shown 
by blue circle; and core sediments from Ganga-Yamuna interfluves (Rahaman et al., 2009) are shown by black circle. The ranges of isotopic variations in GS sediments are several orders of magnitude higher than the analytical uncertainties.

Fig. 7. Photomicrographs of carbonate nodules collected from fluvial sand in the GS-11 core. (a) Full view of two types of nodules shown by arrows; the one on left is light colored comprising relatively bigger grains in micritic groundmass, and the other on right is dark brown colored comprising relatively smaller grains. (b) Light and dark micritic groundmass showing opaque areas (arrows) with diffused margins showing some amount of $\mathrm{Fe}-\mathrm{Mn}$ impregnation. (c) Floating grain texture in which relatively bigger grains show fragmentation with openings filled with microspar. (d) Brown micritic groundmass with floating clasts of quartz, feldspar, and needle shaped mica. (e) Feldspar grain bounded by spar forming corona texture. (f) Clast boundaries show corona texture indicating neomorphic growth of spar.

Fig. 8. Scanning electron microscopy (SEM) images of freshly exposed and polished surfaces of carbonates from fluvial sand in GS cores. (a) Dense micritic matrix embedding quartz grains (arrows), (b) micritic rhombs with etched surfaces and partially filled voids, (c) micritic rhombs showing interstitial voids, (d) micritic calcite crystallization disrupted mica layers (arrows), (e-f) quartz grains embedded in micritic matrix.

Fig. 9. (a) $\delta^{13} \mathrm{C}$ vs. $\delta^{18} \mathrm{O}$ of carbonates from GS-10 and GS-11 drill cores. The GS carbonates hosted in aeolian sand, collected from relatively deeper level $(>37 \mathrm{~m})$, have distinct isotopic composition compared to those hosted in fluvial sand. Also shown for comparison are carbonates from aeolian sediments in NW India (Singhvi et al., 1996; Andrews et al., 1998; Dhir et al., 2004). (b) Comparison of isotopic composition of carbonates from the GS cores with pedogenic carbonates from the Ganga interfluves (Srivastava, 2001; Rahaman et al., 2011) and northwest Bangladesh (Alam et al., 1997). Circle represents compositional field for carbonates hosted in fluvial sand of GS cores.

Fig. 10. Temporal variations in (a-b) ${ }^{87} \mathrm{Sr} /{ }^{86} \mathrm{Sr}$ and $\varepsilon_{\mathrm{Nd}}$ in GS core sediments; (c-d) $\delta^{18} \mathrm{O}$ and $\delta^{13} \mathrm{C}$ of carbonate nodules from GS cores; (e) $\delta^{13} \mathrm{C}$ of soil organic matter from GS cores; (f) Modeled record of change in the strength of SW Indian Monsoon from Prell and Kutzbach (1987); and (g) $\delta^{18} \mathrm{O}$ ice core record from the Guliya ice cap, Qinghai-Tibetan Plateau (Thompson et al., 1997). Also shown for comparison are ${ }^{87} \mathrm{Sr} /{ }^{86} \mathrm{Sr}$ and $\varepsilon_{\mathrm{Nd}}$ in sediments (in a-b; Rahaman et al., 2009), and $\delta^{18} \mathrm{O}$ and $\delta^{13} \mathrm{C}$ values of carbonate nodules (in c-d; Rahaman et al., 2011) in a $~ 50 \mathrm{~m}$ core from the Ganga interfluves. 


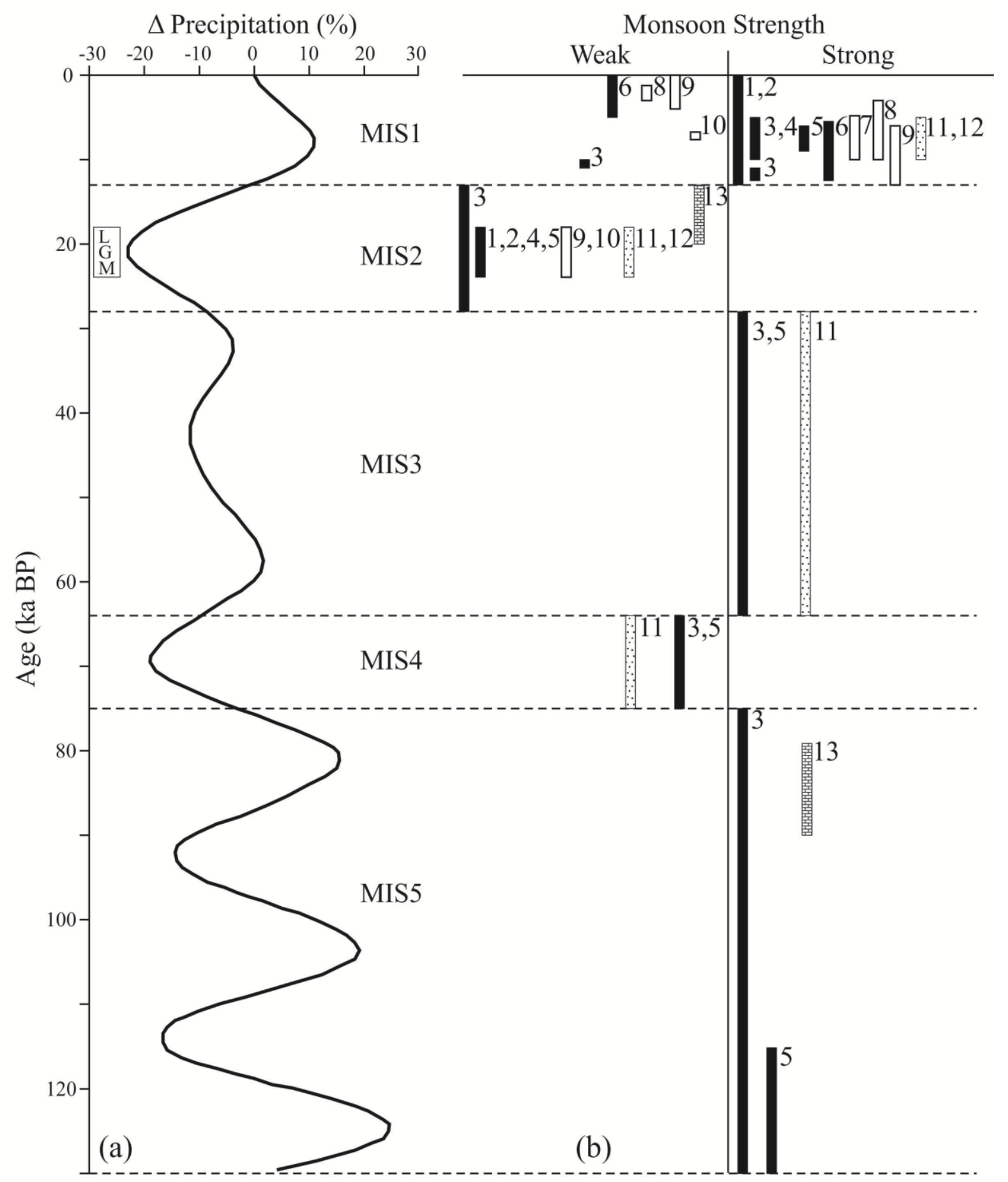

Marine Record Lacustrine Record 冒Aeolian Record 罯Fluvial Record

Figure 1 


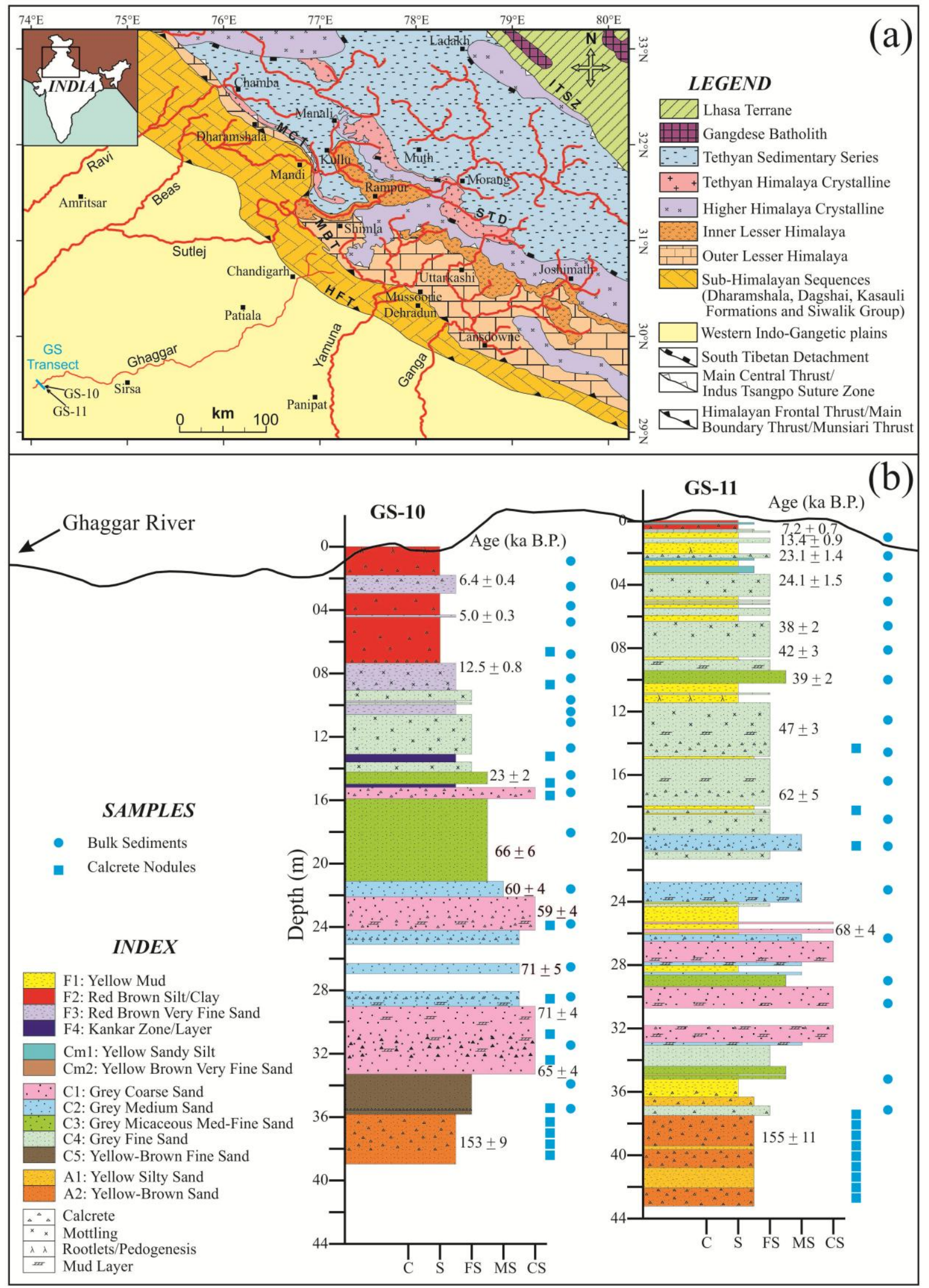

Figure 2 

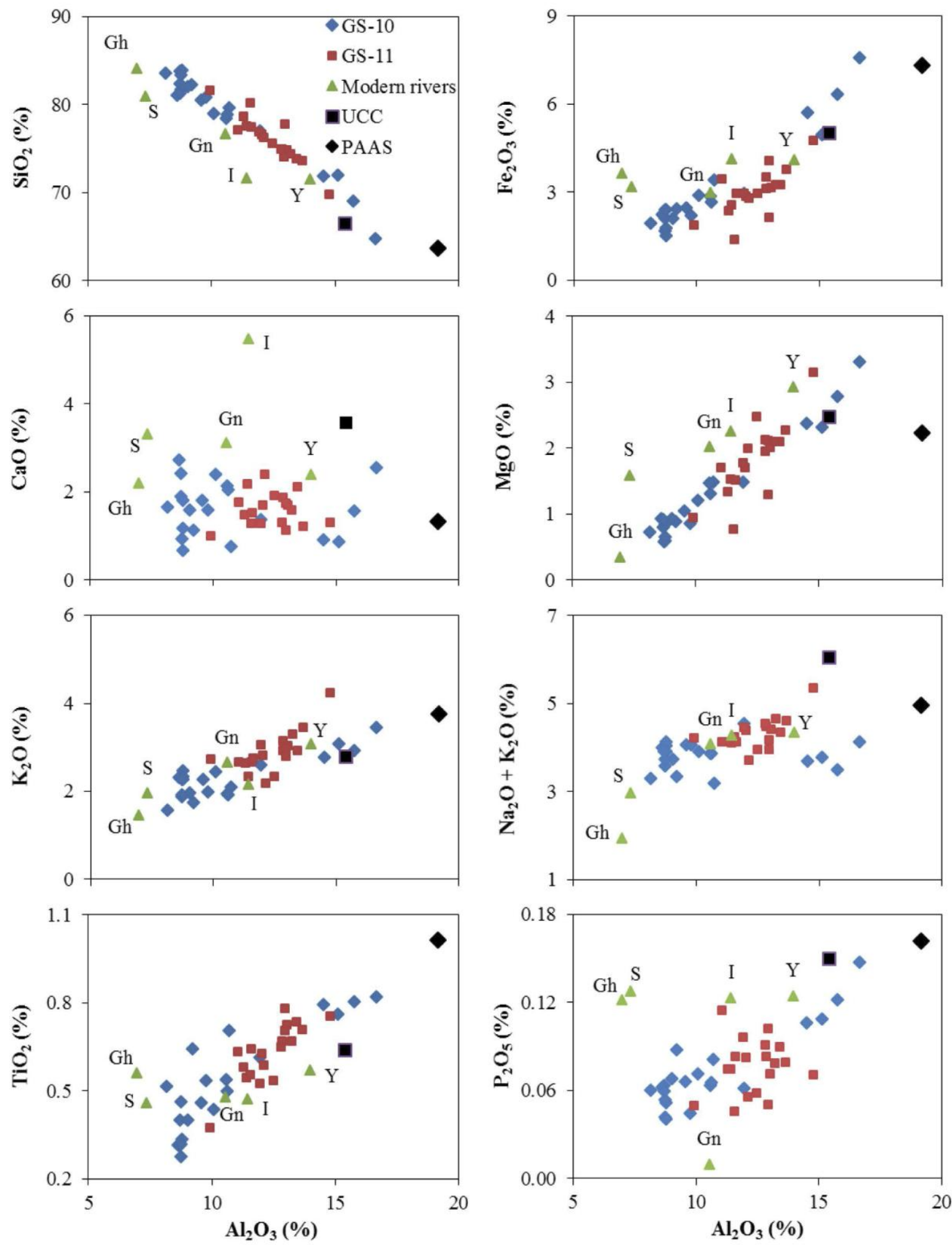

Figure 3 


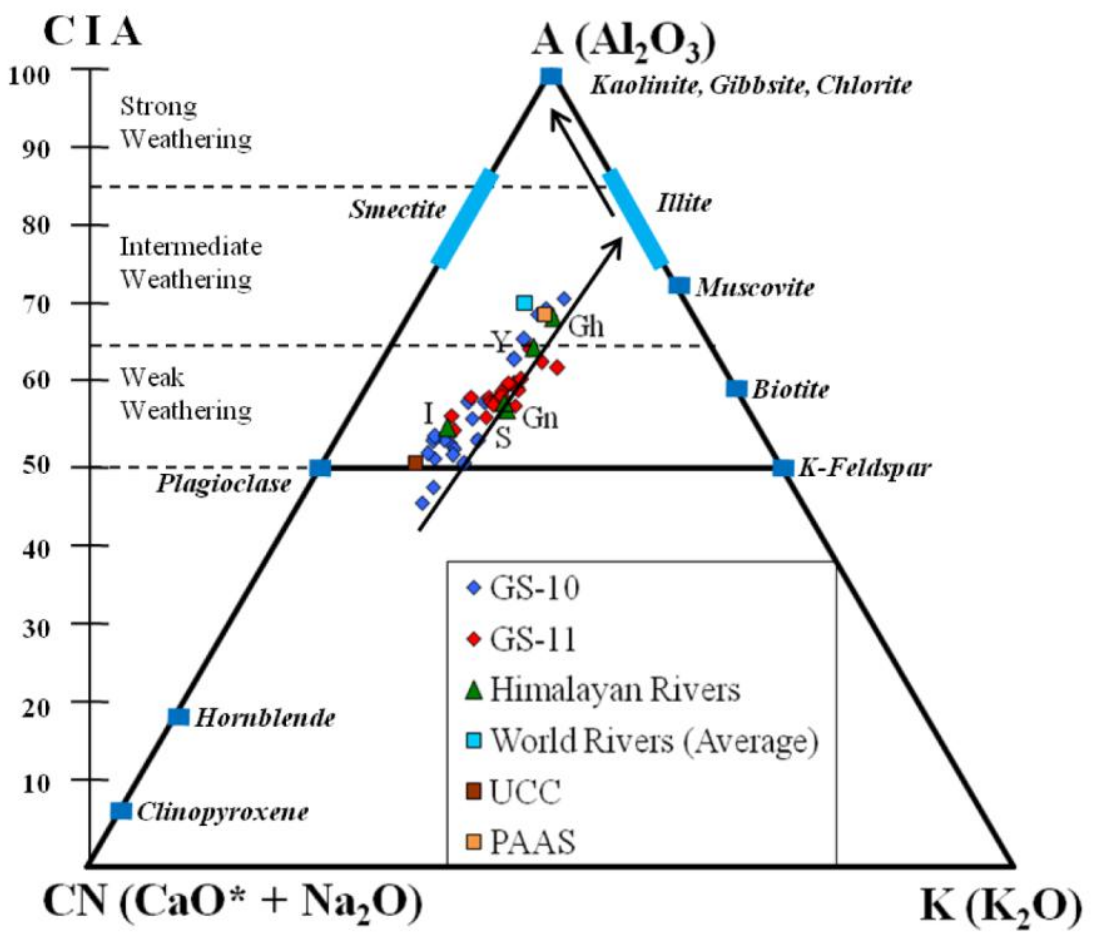

Figure 4 

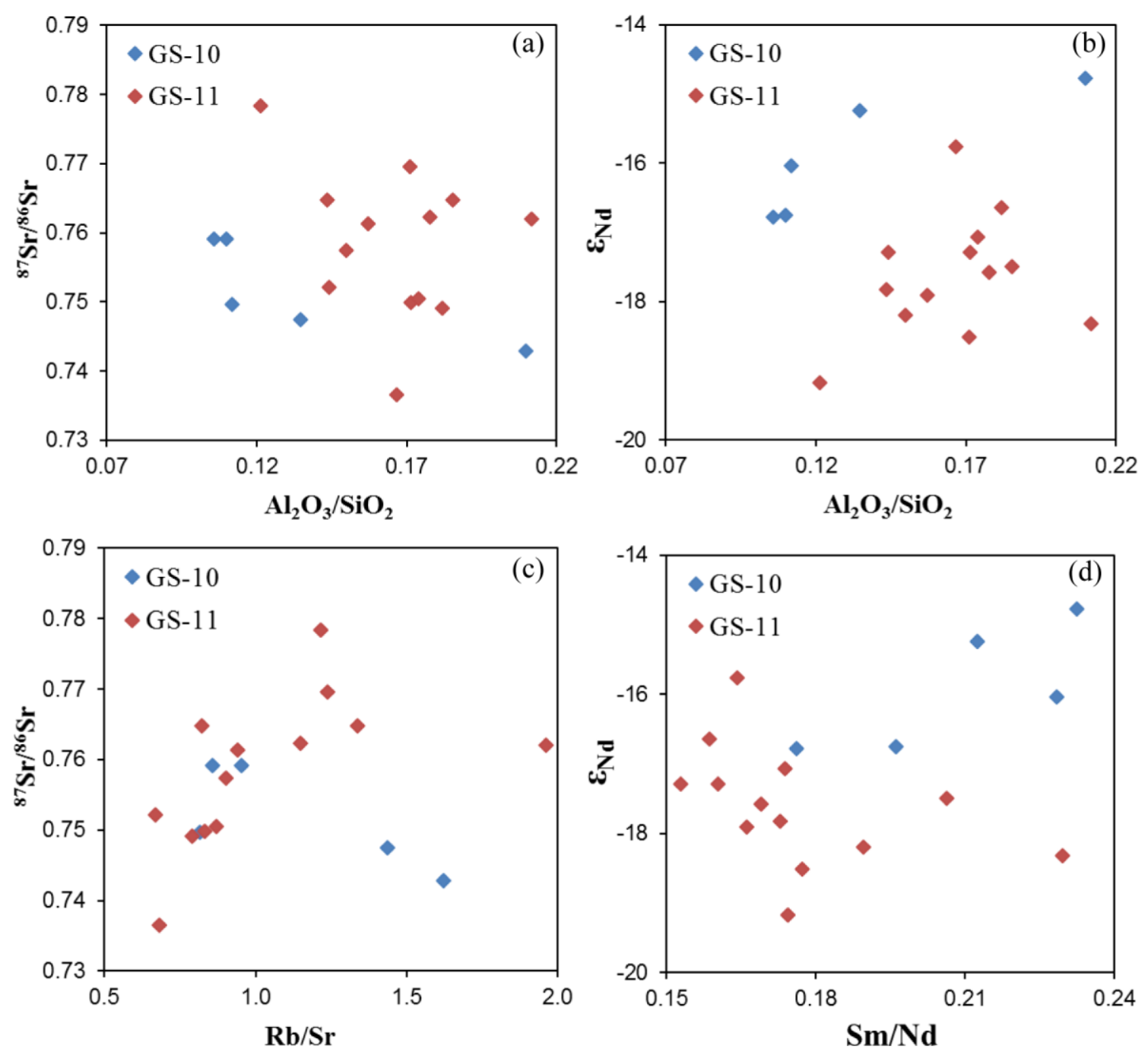

Figure 5 


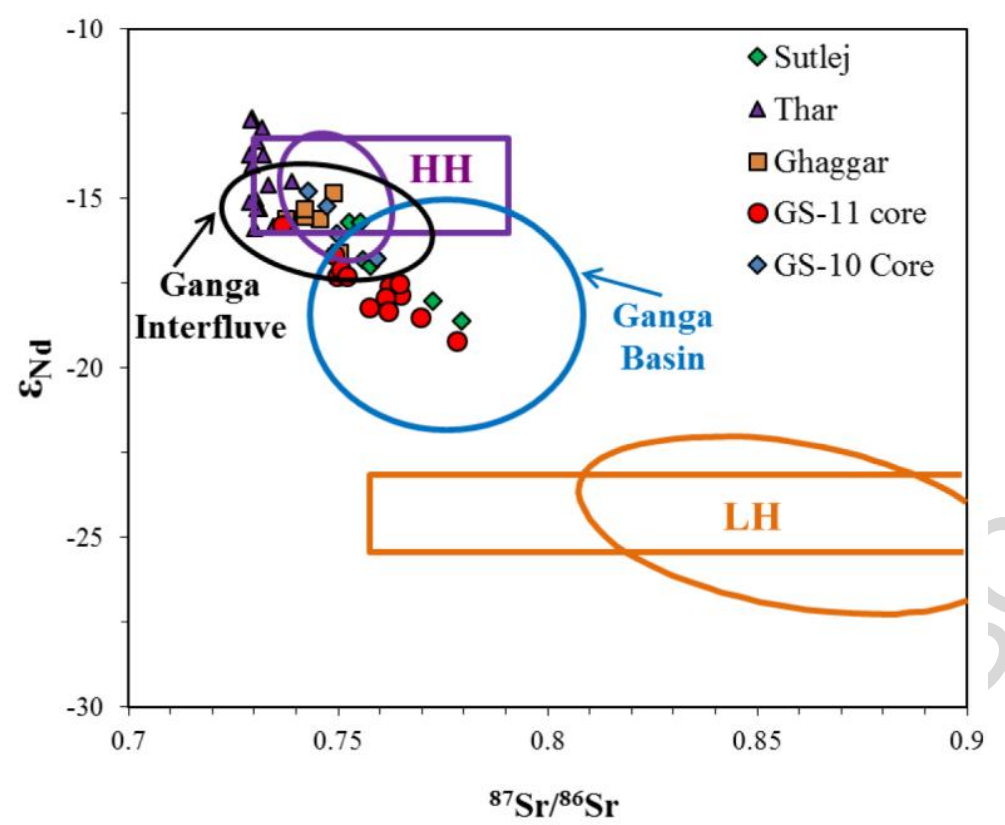

Figure 6 

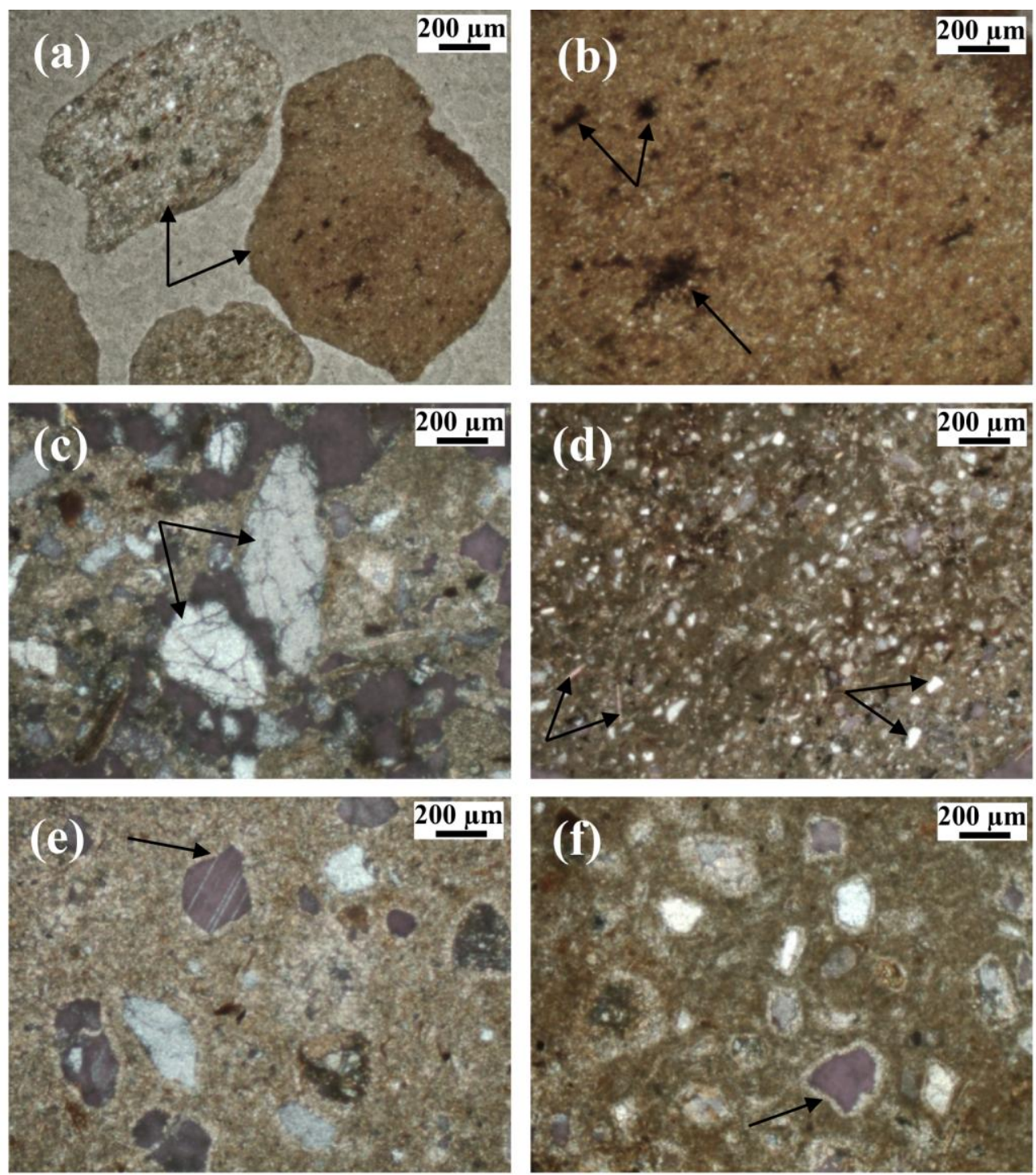

Figure 7

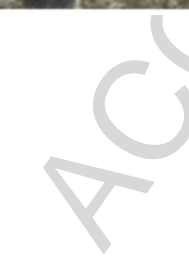



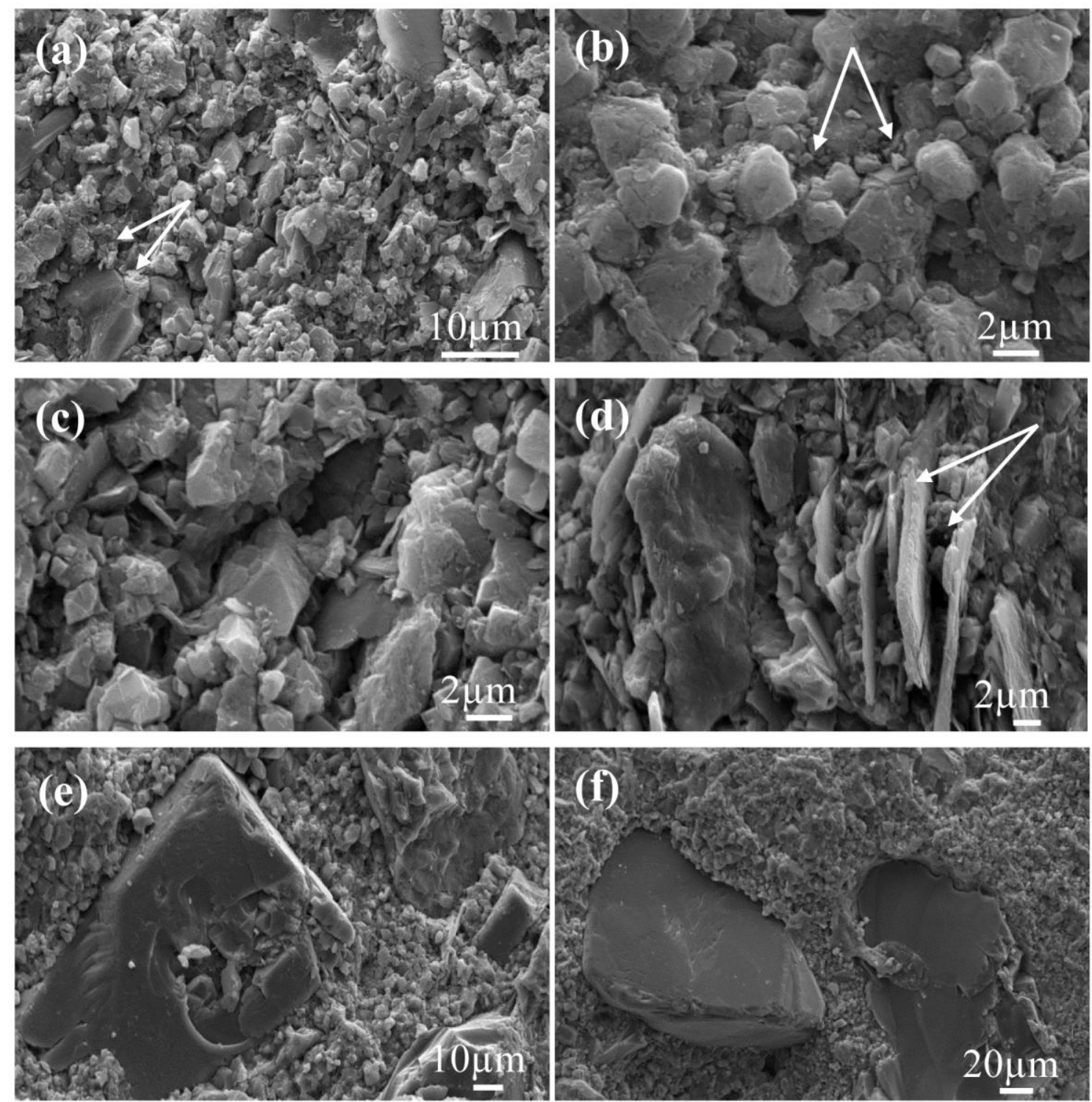

Figure 8 

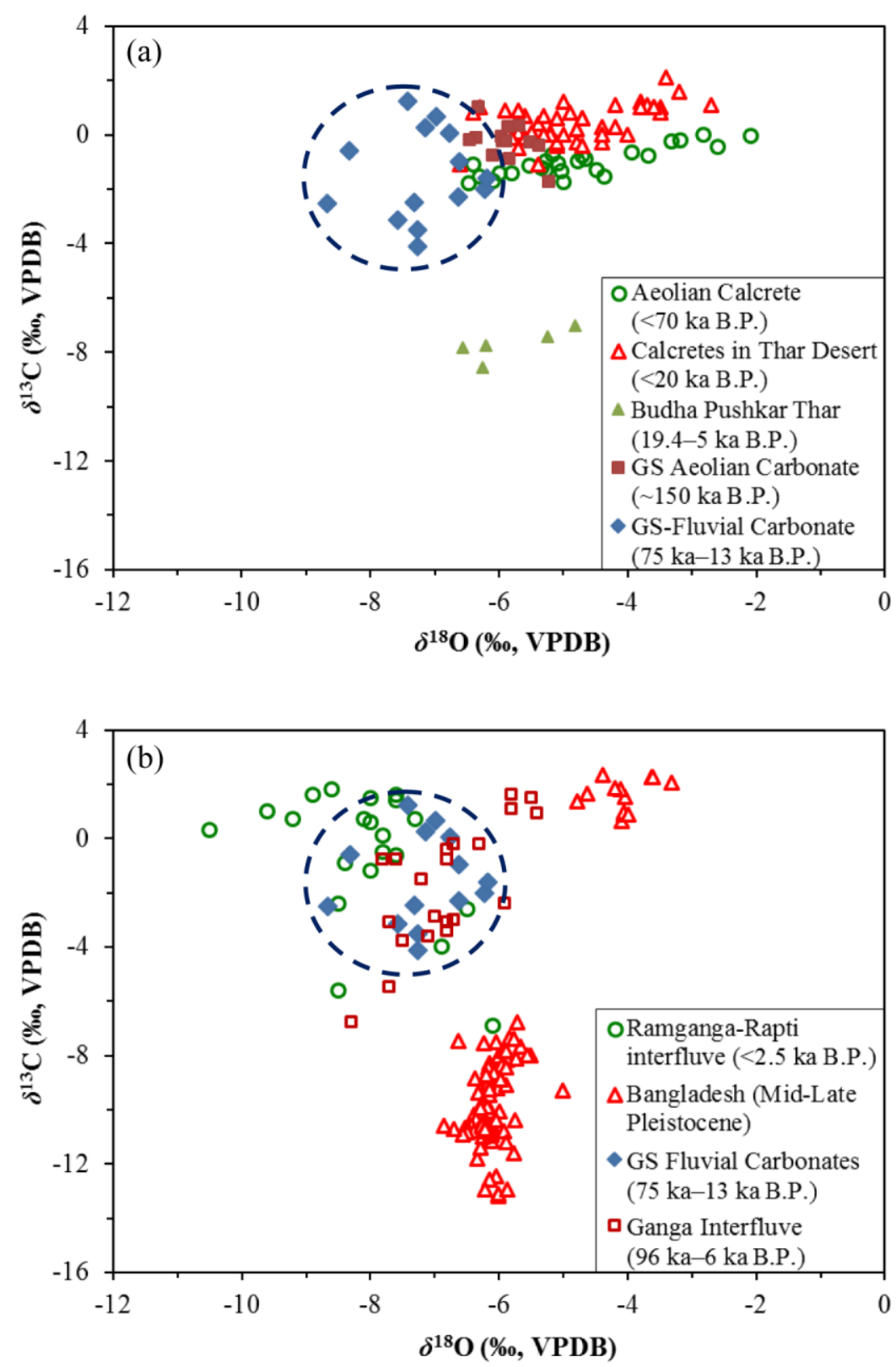

Figure 9 


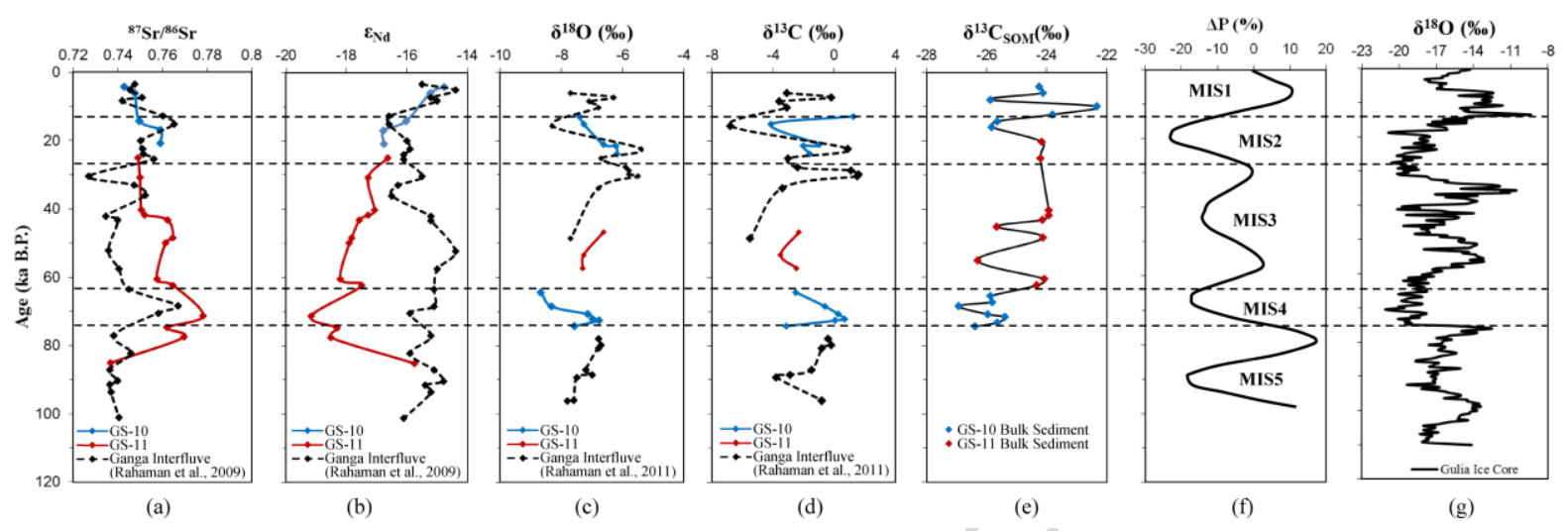

Figure 10 
Table1. ${ }^{87} \mathrm{Sr} /{ }^{86} \mathrm{Sr}$ and ${ }^{143} \mathrm{Nd} /{ }^{144} \mathrm{Nd}$ ratios in the silicate fraction of GS core sediments.

\begin{tabular}{lcccc}
\hline Sample No. & Depth $(\mathrm{m})$ & ${ }^{87} \mathrm{Sr} /{ }^{86} \mathrm{Sr}\left( \pm 2 \sigma_{\mathrm{e}}\right)$ & ${ }^{143} \mathrm{Nd} /{ }^{144} \mathrm{Nd}\left( \pm 2 \sigma_{\mathrm{e}}\right)$ & $\varepsilon_{\mathrm{Nd}}$ \\
\hline GS10-F0 & 1.1 & $0.74287 \pm 1$ & $0.511881 \pm 3$ & -14.6 \\
GS10-F1 & 2.4 & $0.74744 \pm 2$ & $0.511857 \pm 3$ & -15.1 \\
GS10-F5 & 8.3 & $0.74966 \pm 2$ & $0.511816 \pm 3$ & -15.9 \\
GS10-F6-1 & 10.2 & $0.75909 \pm 3$ & $0.511778 \pm 3$ & -16.6 \\
GS10-F8 & 13.0 & $0.75909 \pm 3$ & $0.511779 \pm 4$ & -16.6 \\
GS11-F3 & 3.4 & $0.74907 \pm 1$ & $0.511785 \pm 4$ & -16.5 \\
GS11-F4 & 4.5 & $0.74984 \pm 1$ & $0.511752 \pm 2$ & -17.1 \\
GS11-F4 & 4.5 & $0.74998 \pm 1$ & $0.511782 \pm 2$ & -16.5 \\
GS11-F5 & 6.9 & $0.75045 \pm 1$ & $0.511763 \pm 4$ & -16.9 \\
GS11-F6 & 7.8 & $0.75210 \pm 1$ & $0.511752 \pm 4$ & -17.1 \\
GS11-F7 & 8.7 & $0.76228 \pm 1$ & $0.511737 \pm 4$ & -17.4 \\
GS11-F9 & 12.0 & $0.76478 \pm 1$ & $0.511724 \pm 3$ & -17.7 \\
GS11-F10 & 13.0 & $0.76137 \pm 1$ & $0.511720 \pm 3$ & -17.8 \\
GS11-F12 & 19.7 & $0.75743 \pm 1$ & $0.511705 \pm 3$ & -18.0 \\
GS11-F13 & 20.9 & $0.76472 \pm 1$ & $0.511741 \pm 4$ & -17.3 \\
GS11-F15 & 26.6 & $0.77831 \pm 1$ & $0.511655 \pm 6$ & -19.0 \\
GS11-F16 & 28.8 & $0.76200 \pm 1$ & $0.511699 \pm 5$ & -18.2 \\
GS11-F16 ${ }^{D}$ & 28.8 & $0.76100 \pm 1$ & $0.511707 \pm 5$ & -18.0 \\
GS11-F17 & 30.6 & $0.76962 \pm 2$ & $0.511689 \pm 3$ & -18.4 \\
GS11-F18 & 35.4 & $0.73655 \pm 1$ & $0.511830 \pm 3$ & -15.6 \\
\hline
\end{tabular}

Note: $\varepsilon_{\mathrm{Nd}}=\left[\left({ }^{143} \mathrm{Nd} /{ }^{144} \mathrm{Nd}_{\text {sample }} /{ }^{143} \mathrm{Nd} /{ }^{144} \mathrm{Nd}_{\mathrm{CHUR}}\right)-1\right] \times 10,000 . \varepsilon_{\mathrm{Nd}}$ is the fractional deviation of ${ }^{143} \mathrm{Nd} /{ }^{144} \mathrm{Nd}$ ratio, in units of parts per 10,000 , from its value in the present-day CHUR (chondritic uniform reservoir) of 0.512630 (Bouvier et al., 2008). Error reported is 2 standard error of the mean based on in-run statistics. Errors should be read as the last digit; for example, the $\mathrm{Sr}$ isotope ratio for GS10-F0 should be read as $0.74287 \pm 0.00001$. Superscript D refers to duplicate measurement. 
Table 2. $\delta^{18} \mathrm{O}$ and $\delta^{13} \mathrm{C}$ of carbonate nodules from GS cores. Also given are sampling depths of host sediments containing the nodules.

\begin{tabular}{|c|c|c|c|}
\hline \multirow[t]{2}{*}{ Sample No. } & \multirow[t]{2}{*}{ Depth $(\mathrm{m})$} & $\delta^{18} \mathrm{O}$ & $\delta^{13} \mathrm{C}$ \\
\hline & & \multicolumn{2}{|c|}{$(\%$ VPDB $)$} \\
\hline \multicolumn{4}{|c|}{ GS-10 (Fluvial Hosted) } \\
\hline GS10KN1 & 7.3 & -7.42 & 1.24 \\
\hline GS10KN3 & 9.0 & -7.26 & -4.12 \\
\hline GS10KN4 & 13.2 & -6.62 & -0.97 \\
\hline GS10KN5 & 13.5 & -6.22 & -2 \\
\hline GS10KN6 & 15.1 & -6.18 & -1.6 \\
\hline GS10KN7 & 15.6 & -8.67 & -2.52 \\
\hline GS10KN9 & 24.0 & -8.32 & -0.59 \\
\hline GS10KN11 & 28.5 & -7.14 & 0.27 \\
\hline GS10KN12 & 31.2 & -6.98 & 0.66 \\
\hline GS10KN13 & 32.2 & -6.77 & 0.06 \\
\hline GS10KN14 & 35.5 & -7.57 & -3.15 \\
\hline \multicolumn{4}{|c|}{ GS-10 (Aeolian Hosted) } \\
\hline GS10KN15 & 36.2 & -5.52 & -0.26 \\
\hline GS10KN16 & 36.5 & -5.39 & -0.38 \\
\hline GS10KN17 & 36.7 & -5.89 & -0.2 \\
\hline GS10KN18 & 37.9 & -5.69 & 0.35 \\
\hline \multicolumn{4}{|c|}{ GS-11 (Fluvial Hosted) } \\
\hline GS11 KN1 & 14.2 & -6.63 & -2.3 \\
\hline GS11 KN3 & 18.4 & -7.27 & -3.5 \\
\hline GS11 KN4 & 20.9 & -7.31 & -2.47 \\
\hline \multicolumn{4}{|c|}{ GS-11 (Aeolian Hosted) } \\
\hline GS11 KN8 & 37.6 & -6.36 & -0.08 \\
\hline GS11 KN9 & 37.9 & -6.47 & -0.19 \\
\hline GS11 KN10 & 38.3 & -5.96 & -0.05 \\
\hline GS11 KN12 & 38.9 & -5.95 & -0.22 \\
\hline GS11 KN13 & 39.3 & -5.87 & 0.31 \\
\hline GS11 KN14 & 41.3 & -6.10 & -0.75 \\
\hline GS11 KN15 & 41.9 & -5.23 & -1.72 \\
\hline GS11 KN16 & 42.6 & -5.85 & -0.87 \\
\hline GS11 KN17 & 43.2 & -6.32 & 1.05 \\
\hline
\end{tabular}


Table 3. $\delta^{13} \mathrm{C}$ (\%o VPDB) of bulk sediment organic matter from GS-10 and 11 cores.

\begin{tabular}{lcclcc} 
Sample No & Depth $(\mathrm{m})$ & $\delta^{13} \mathrm{C}(\%$ o & Sample No & Depth $(\mathrm{m})$ & $\delta^{13} \mathrm{C}(\%$ o) \\
\hline GS10 F0 & 1.1 & -24.2 & GS10 F17 & 33.5 & -25.6 \\
GS10 F1 & 2.4 & -24.1 & GS10 F18 & 35.8 & -26.4 \\
GS10 F2 & 3.8 & -25.7 & GS11 F2 & 2.5 & -24.1 \\
GS10 F3 & 5.2 & -23.2 & GS11 F2 & 2.5 & -24.1 \\
GS10 F4 & 6.9 & -23.8 & GS11 F3 & 3.4 & -24.2 \\
GS10 F5 & 8.3 & -25.6 & GS11 F5 & 6.9 & -23.9 \\
GS10 F6 & 9.5 & -26.2 & GS11 F6 & 7.8 & -23.9 \\
GS10 F11 & 18.0 & -25.9 & GS11 F7 & 8.7 & -24.2 \\
GS10 F12 & 21.4 & -25.9 & GS11 F8 & 9.9 & -24.9 \\
GS10 F13 & 23.8 & -27.4 & GS11 F9 & 12.0 & -24.1 \\
GS10 F13 & 23.8 & -26.9 & GS11 F11 & 16.5 & -25.5 \\
GS10 F15 & 28.6 & -26.0 & GS11 F12 & 19.7 & -24.1 \\
GS10 F16 & 30.2 & -25.3 & GS11 F13 & 20.9 & -24.3 \\
\hline
\end{tabular}

Note: Superscript D refers to duplicate measurement. 
Research Highlights of the manuscript "Geochemistry of buried river sediments from Ghaggar Plains, NW India: multi-proxy records of variations in provenance, paleoclimate, and paleovegetation patterns in the Late Quaternary".

- We report first chemical record of buried sediments from Ghaggar Plains, India.

- Alluvial sediments were derived from Higher and Lesser Himalayan endmembers.

- Geochemical proxies support climate-controlled erosion in the Himalayan catchment.

- Source was dominated by $\mathrm{C}_{3}$ plants for the past $75 \mathrm{ka}$.

- $\mathrm{C}_{3}: \mathrm{C}_{4}$ ratio changed as a response to intensity of summer rainfall. 